\title{
Interannual variability of the carbon balance of three different-aged Douglas-fir stands in the Pacific Northwest
}

\author{
Praveena Krishnan, ${ }^{1,2}$ T. Andrew Black, ${ }^{1}$ Rachhpal S. Jassal, ${ }^{1}$ \\ Baozhang Chen, ${ }^{3,4}$ and Zoran Nesic ${ }^{1}$ \\ Received 13 December 2008; revised 9 June 2009; accepted 28 July 2009; published 24 November 2009.
}

[1] The seasonal and interannual variability of gross ecosystem photosynthesis $\left(P_{g}\right)$ and ecosystem respiration $\left(R_{e}\right)$, and their relationships to environmental variables and stand characteristics were used to explain the variation of eddy-covariance-measured net ecosystem productivity $\left(F_{N E P}\right)$ of three different-aged Douglas-fir stands located on the east coast of Vancouver Island in British Columbia, Canada. During the 9-year period, 1998-2006, which included a strong El Niño/La Niña event, the near-end-of-rotation stand (DF49, 57 years old in 2006) was a moderate carbon (C) sink for $\mathrm{CO}_{2}$ with annual $F_{N E P}$ ranging from 267 to $410 \mathrm{~g} \mathrm{C} \mathrm{m}^{-2} \mathrm{yr}^{-1}$ (mean $\pm \mathrm{SD}, 357 \pm 51 \mathrm{~g} \mathrm{C} \mathrm{m}^{-2} \mathrm{yr}^{-1}$ ). The pole/sapling stand (HDF88, 18 years old in 2006) was a weak $\mathrm{C}$ source $\left(F_{N E P}=\right.$ $-64 \pm 75 \mathrm{~g} \mathrm{C} \mathrm{m}^{-2} \mathrm{yr}^{-1}$ ), and the recently harvested stand (HDF00, 6 years old in 2006) was a large $\mathrm{C}$ source $\left(F_{N E P}=-515 \pm 88 \mathrm{~g} \mathrm{C} \mathrm{m}^{-2} \mathrm{yr}^{-1}\right)$ during 2002-2006. Irrespective of stand age, all sites responded quite similarly to changes in environmental variables during each year. Daily total values of $P_{g}$ and $R_{e}$ were highest in July-August in all three stands, while daily $F_{N E P}$ peaked during April-June at DF49, May-June at HDF88, and June-July at HDF00. Reductions in root-zone soil water content decreased both $P_{g}$ and $R_{e}$ especially during the dry period from May to September, and this effect was more pronounced in the younger stands. Evapotranspiration and dry-foliage surface conductance also decreased with decreasing root-zone soil water content whereas water use efficiency appeared to be conservative, especially at DF49. Increasing spring temperature had a positive effect on annual $P_{g}$ and $R_{e}$ but caused a slight decrease in annual $F_{N E P}$. During the summer to autumn transition period, increases in soil water content resulted in a greater increase in $R_{e}$ than $P_{g}$ causing a reduction in $F_{N E P}$. The interannual variation in the $\mathrm{C}$ balance was determined mainly by the interannual variation in $R_{e}$ for the near-end-of-rotation stand and $P_{g}$ for the two younger stands. The results indicate that regardless of the stand age, interannual variability in the $\mathrm{C}$ balance was mainly determined by year-to-year variability in spring temperature and water availability in late summer.

Citation: Krishnan, P., T. A. Black, R. S. Jassal, B. Chen, and Z. Nesic (2009), Interannual variability of the carbon balance of three different-aged Douglas-fir stands in the Pacific Northwest, J. Geophys. Res., 114, G04011, doi:10.1029/2008JG000912.

\section{Introduction}

[2] Characterizing the effects of the interannual variability of climate on the carbon (C) balance of ecosystems is necessary for understanding the causes of the interannual variability of global $\mathrm{CO}_{2}$ budget and also predicting

\footnotetext{
${ }^{1}$ Biometeorology and Soil Physics Group, Faculty of Land and Food Systems, University of British Columbia, Vancouver, British Columbia, Canada.

${ }^{2}$ Now at Atmospheric Turbulence and Diffusion Division, NOAA, Oak Ridge, Tennessee, USA.

${ }^{3}$ Department of Forest Resources Management, Faculty of Forestry, University of British Columbia, Vancouver, British Columbia, Canada.

${ }^{4}$ Now at Institute of Geographic Science and Natural Resources Research, Chinese Academy of Sciences, Beijing, China.

the consequences of projected climate change in response to increasing global temperature [Barford et al., 2001; Intergovernmental Panel on Climate Change (IPCC), 2007]. Even though the northern high-latitude boreal and temperate forest biomes are known to be sinks for atmospheric $\mathrm{CO}_{2}$ [Keeling et al., 1996; Myneni et al., 1997; Sellers et al., 1997; Schimel et al., 2001], ecophysiological factors can change an ecosystem from a $\mathrm{C}$ sink to a $\mathrm{C}$ source or vice versa [Goulden et al., 1996; Lindroth et al., 1998; Dunn et al., 2007]. In addition to climatic variability, land use change, changes in age distribution and species composition, recovery and response time of a forest ecosystem from a past disturbance like fire, harvesting and insect defoliation can alter the magnitude of $\mathrm{C}$ gain or loss by an ecosystem over diurnal, seasonal, annual and longer timescales. This suggests that for accurately determining the contribution of forested ecosystems to the global $\mathrm{C}$ budget and also for 
assessing the impact of climate change and alternative land use at landscape and regional scales, adequate understanding of the processes that control net $\mathrm{CO}_{2}$ exchange of different vegetation types over the course of stand development is required [Turner et al., 2000]. This information is also crucial to quantify and predict vegetation feedback on the climate system [Cramer et al., 2001; Heimann and Reichstein, 2008].

[3] The $\mathrm{C}$ balance at the ecosystem level (net ecosystem productivity, $\left.F_{N E P}\right)$ is the difference between gross ecosystem photosynthesis $\left(P_{\mathrm{g}}\right)$ and ecosystem respiration $\left(R_{e}\right)$ and is typically almost an order of magnitude smaller than these nearly offsetting components. Assessing the factors controlling $F_{N E P}$ from diurnal to interannual timescales is challenging because of the complexity of the processes controlling its components. Previous studies have reported that both $P_{g}$ and $R_{e}$ are highly sensitive to changes in solar irradiance, temperature, water availability and leaf area index (LAI) in temperate [Reichstein et al., 2002, 2007] and boreal [Barr et al., 2007; Krishnan et al., 2006, 2008] stands. There is an ongoing debate about which component largely controls the interannual variation in $F_{N E P}$ for various ecosystems. Studies on southern boreal ecosystems, where the growing season is short, show that an increase in spring temperature causes an increase in annual $F_{N E P}$ by causing earlier leaf emergence in deciduous forest and $P_{g}$ to increase faster than $R_{e}$ in coniferous forests [Black et al., 2000, 2005; Barr et al., 2002]. However, Valentini et al. [2000] reported that $R_{e}$ was the main determinant of the variation in the $\mathrm{C}$ balance along a continental gradient in Europe. Studies have shown that the $\mathrm{C}$ balance of a forest varies dramatically during stand development by changing its status from a $\mathrm{C}$ source in the early stages of development to a $\mathrm{C}$ sink in the intermediate and mature stages, and can even maintain its status as a sink or turn into a $\mathrm{C}$ source as it ages [Schulze et al., 1999; Amiro et al., 2005; Chen et al., 2002; Clark et al., 2004; Bond-Lamberty et al., 2004; Humphreys et al., 2006; McMillan et al., 2008]. The above studies showed how stand age influences annual $F_{N E P}$; however, the information on how climate causes interannual variation in ecosystem $\mathrm{C}$ exchange at different stages of development following disturbance is lacking. Long-term measurements are needed to quantify the interannual variability of $\mathrm{C}$ exchange at different ages of the stand, to relate these differences to environmental forcings, and to determine the presence of long-term trends. In this context, direct, longterm measurement of $\mathrm{CO}_{2}$ fluxes using the eddy-covariance (EC) technique permits the assessment of the $\mathrm{C}$ exchange at different stages of development.

[4] In this paper, we examine the interannual variation in the $\mathrm{C}$ balance of three Pacific Northwest (PNW) Douglas-fir (Pseudotsuga menziesii var. menziesii (Mirb.) Franco stands at different stages of development after harvesting. Coastal Douglas-fir occurs in a large geographical region (>20 million ha) in the PNW from central California to the midcoast of British Columbia (BC) [Hermann, 1985] and likely plays a significant role in the global $\mathrm{C}$ cycle. The forests of the PNW, which are often dominated by Douglasfir, a commercially desirable timber species, store more C per unit area than any other forested area of North America [Turner et al., 1995] and with improved management are capable of storing more $\mathrm{C}$ than they do at present [Smithwick et al., 2002]. The climate in the PNW, which is characterized by wet mild winters and warm and dry summers, contrasts strikingly with other temperate forest regions in eastern United States, eastern Asia and Europe as they have a more even distribution of precipitation during the year with no reduction during the growing season [Waring and Franklin, 1979]. El Niño-Southern Oscillation (ENSO) with a periodicity of 2-7 years [Rasmussen and Wallace, 1983)] and Pacific decadal oscillations (PDO), primarily on decade-todecade timescales, have been identified as key sources of interannual climate variations in the PNW. Warm phases of ENSO (El Niño) and PDO typically induce warmer and drier conditions in the PNW, while cool phases of ENSO (La Niña) and PDO bring cooler, wetter weather to the region [Rasmussen and Wallace, 1983; Case and Peterson, 2005]. In a recent analysis on trends in temperature and precipitation in the PNW, Mote et al. [1999] and Mote [2003] found that temperature and precipitation have increased more than their respective global averages and this is likely to continue with increased precipitation mostly occurring in winter. In this context, it is important to investigate the impact of climate variability on the $\mathrm{C}$ balance and how these ecosystems may respond to projected climate change.

[5] The study sites included a young plantation, a pole/ sapling stand and a near-end-of-harvest-rotation stand (hereafter referred to as HDF00, HDF88 and DF49, respectively). Previous studies on this chronosequence have focused on the climatic sensitivity and uncertainty of the $\mathrm{C}$ balance [Morgenstern et al., 2004], soil and ecosystem respiration [Drewitt et al., 2002; Jassal et al., 2007, 2008a], and variability and controls of sensible heat, latent heat and $\mathrm{CO}_{2}$ fluxes [Humphreys et al., 2003, 2005, 2006; Jassal et al., 2008b]. In this paper, we focus on the interannual variability in the $\mathrm{C}$ balance of the chronosequence. The main objectives of this paper are (1) to examine the seasonal and interannual variation in $F_{N E P}, P_{g}$ and $R$ of the three stands, (2) to determine the responses of $P_{g}$ and $R_{e}$ to environmental variables at different stages of stand development, and (3) to understand the processes controlling the interannual variability of $F_{N E P}, P_{g}$ and $R_{e}$.

\section{Materials and Methods}

\subsection{Study Sites}

[6] The three stands are located between Buckley Bay and Campbell River within $13 \mathrm{~km}$ of Georgia Strait on the east coast of Vancouver Island, BC, Canada. The oldest stand (DF49) was planted with Douglas-fir seedlings in 1949 after the original stand was logged in 1937 and slash-burned in 1943. In 2004, it was composed of $80 \%$ Douglas-fir, $17 \%$ western red cedar (Thuja plicata Donn) and 3\% western hemlock (Tsuga heterophylla (Raf.) Sarg.) [Humphreys et al., 2006] and its leaf area index (LAI) was 7.3 [Chen et al., 2006]. DF49 is a 130-ha stand on a $5-10^{\circ} \mathrm{NE}$ facing slope located only $3 \mathrm{~km} \mathrm{NWN}$ of the plantation (HDF00), which was clear-cut-harvested in the 1999/2000 winter and planted in the spring of 2000 with 1-year-old seedlings (93\% Douglas-fir and 7\% western red cedar). About $48 \mathrm{~km}$ SE of these two sites is the pole/sapling stand (HDF88) established in 1988. This stand was clear-cut in 1987, burned, planted in 1988 with $75 \%$ Douglas-fir, 25\% western red cedar and 4\% grand fir (Abies grandis var. grandis) and sprayed with herbicide to control competing brush in 1992. 
Table 1. Sites Characteristics

\begin{tabular}{|c|c|c|c|}
\hline & DF49 & HDF88 & HDF00 \\
\hline Location & $49^{\circ} 52^{\prime} 7.8^{\prime \prime} \mathrm{N}, 125^{\circ} 20^{\prime} 6.3^{\prime \prime} \mathrm{W}$ & $49^{\circ} 32^{\prime} 10.49^{\prime \prime} \mathrm{N}, 124^{\circ} 54^{\prime} 7.18^{\prime \prime} \mathrm{W}$ & $49^{\circ} 52^{\prime} 1.08^{\prime \prime} \mathrm{N}, 125^{\circ} 16^{\prime} 43.80^{\prime \prime} \mathrm{W}$ \\
\hline Elevation (m) & 320 & 173 & 188 \\
\hline Slope (deg) & $5-10 \mathrm{NE}$ & $2-5 \mathrm{SE}$ & $0-2$ \\
\hline Stand height ${ }^{\mathrm{a}}(\mathrm{m})$ & 34 & 7 & 0.8 \\
\hline Distance from coastline $(\mathrm{km})$ & 15.7 & 3.1 & 11.6 \\
\hline Stand density ${ }^{\mathrm{a}}\left(\right.$ trees $\left.\mathrm{ha}^{-1}\right)$ & 1150 & 1240 & 1500 \\
\hline Stand area (ha) & 130 & 110 & 32 \\
\hline $\begin{array}{l}80 \% \text { cumulative flux footprint area } \\
\text { (annual average })^{\mathrm{b}} \text { (ha) }\end{array}$ & 93 & 17 & 8 \\
\hline Mean DBH $(\mathrm{cm})$ & 28.3 & 7.3 & 1.02 (at base) \\
\hline Woody debris biomass ${ }^{\mathrm{c}}\left(\mathrm{kg} \mathrm{m}^{-2}\right)$ & $0.7-10$ & $3.4-16.5$ & $0.5-2.2$ \\
\hline Live aboveground biomass ${ }^{\mathrm{c}}\left(\mathrm{kg} \mathrm{m}^{-2}\right)$ & $8.5-23.0$ & $0.8-2.1$ & $<0.1-0.4$ \\
\hline Total aboveground biomass ${ }^{\mathrm{d}}\left(\mathrm{kg} \mathrm{m}^{-2}\right)$ & 13.81 & 1.139 & 0.165 \\
\hline Total belowground biomass ${ }^{\mathrm{d}}\left(\mathrm{kg} \mathrm{m}^{-2}\right)$ & 1.25 & - & - \\
\hline Tree cover type & $\begin{array}{l}77 \% \text { Douglas-fir, } 18 \% \\
\text { western red cedar, } \\
4.6 \% \text { western hemlock }\end{array}$ & $\begin{array}{l}75 \% \text { Douglas-fir, } 21 \% \\
\text { western red cedar, } \\
\text { and } 4 \% \text { grand fir }\end{array}$ & $\begin{array}{c}97 \% \text { Douglas-fir, } 3 \% \\
\text { western red cedar }\end{array}$ \\
\hline Understory & $\begin{array}{l}\text { Vanilla leaf deerfoot, } \\
\text { Oregon grape, mosses }\end{array}$ & $\begin{array}{l}\text { Salal, Oregon grape, } \\
\text { fireweed and bracken } \\
\text { fern, huckleberry }\end{array}$ & $\begin{array}{l}\text { Grasses, sword and bracken } \\
\text { fern, herbs, woody shrubs: } \\
\text { twinflower, honeysuckle } \\
\text { rubrus spp., Oregon grape }\end{array}$ \\
\hline Stand history & $\begin{array}{l}\text { Clear-cut, slash burned, } \\
\text { planted stock mixed } \\
\text { with natural regeneration }\end{array}$ & $\begin{array}{l}\text { Clear-cut, broadcast burned, } \\
\text { planted }\end{array}$ & Clear-cut, planted \\
\hline $\mathrm{LAI}^{\mathrm{e}, \mathrm{f}}\left(\mathrm{m}^{2} \mathrm{~m}^{-2}\right)$ & 7.3 & $3.0-7.2$ & $0.3-2.5$ \\
\hline Soil classification & Humo-ferric podzol & Humo-ferric podzol & Humo-ferric podzol \\
\hline Soil texture & Gravelly loamy sand & Gravelly loam & Gravelly loamy sand to sand \\
\hline Soil organic layer $(\mathrm{cm})$ & 3 & 4.1 & 3.6 \\
\hline Flux measurement height (m) & 42 & 12 & 2.5 \\
\hline$u *$ threshold $(u * T)\left(\mathrm{m} \mathrm{s}^{-1}\right)$ & 0.30 & 0.16 & 0.08 \\
\hline Mean annual temperature ${ }^{\mathrm{g}}\left({ }^{\circ} \mathrm{C}\right)$ & 8.4 & 9.6 & 8.9 \\
\hline Mean annual rainfall ${ }^{\mathrm{g}}(\mathrm{mm})$ & 1245 & 1546 & 1227 \\
\hline
\end{tabular}

${ }^{\mathrm{a}}$ Stand height and density is for live trees in 2002.

${ }^{\mathrm{b}}$ Chen et al. [2009].

${ }^{\mathrm{c}}$ Both woody debris and live biomasses are the sum of all aboveground tree components and understory vegetation [Humphreys et al., 2006].

${ }^{\mathrm{d}}$ Total aboveground biomass is the sum of tree wood, tree foliage, shrub, nonwoody biomass while total belowground biomass is the sum of fine root and coarse root biomass.

${ }^{\mathrm{e}} \mathrm{LAI}$ at DF49 [Chen et al., 2006].

${ }^{\mathrm{f}}$ Seasonal range of stand LAI values in 2002 at HDF88 and HDF00 [Humphreys et al., 2006].

${ }^{\mathrm{g}}$ Mean values during 1998-2006 for DF49 and 2002-2006 for HDF88 and HDF00, respectively.

The chronosequence is part of the seasonal dry variety of the temperate rain forest that covers much of North America's PNW in the coastal western hemlock $(\mathrm{CWH})$ biogeoclimatic zone [Meidinger and Pojar, 1991]. Even though the three stands were located in very similar ecosystems and experienced similar weather, there were differences in elevation and soil characteristics between the sites. Key stand and soil attributes, and flux-footprint areas at each site are given in Table 1 and further details are provided elsewhere [Morgenstern et al., 2004; Humphreys et al., 2006; Chen et al., 2009]. The prevailing wind directions at the sites were NE to $\mathrm{E}$ during daytime and $\mathrm{SW}$ to $\mathrm{W}$ during nighttime, and are attributed to the topography and land-sea circulation due to the sites' proximity to Georgia Strait.

\subsection{Eddy-Covariance Flux Measurements}

[7] Continuous, half-hourly turbulent fluxes of $\mathrm{CO}_{2}$, water vapor $(E)$ and sensible heat $(H)$ were measured above the canopy using the EC technique [Morgenstern et al., 2004; Humphreys et al., 2005, 2006]. EC fluxes were measured at all sites above the canopy (Table 1) using a threedimensional sonic anemometer-thermometer (Model R2 or R3, Gill Instruments, Lymington, UK) and a closed-path, temperature-controlled infrared gas $\left(\mathrm{CO}_{2} / \mathrm{H}_{2} \mathrm{O}\right)$ analyzer (IRGA) (model LI-6262, LI-COR Inc., Lincoln, NE, USA) or open-path IRGA (HDF88 up to 2003, model LI-7500, LI-COR Inc.). Closed-path IRGA analog signals $\left(\mathrm{CO}_{2}\right.$ and $\mathrm{H}_{2} \mathrm{O}$ mole fractions) were sampled at $125 \mathrm{~Hz}$ with a data acquisition system (Model DaqBook/200, Iotech Inc., Cleveland, OH, USA), digitally filtered and down sampled to $20.83 \mathrm{~Hz}$ and transferred every half-hour to a site computer for further flux calculations. Further details on the experimental setup, calibration and eddy flux calculations can be found in the works of Morgenstern et al. [2004] and Humphreys et al. [2006].

\subsection{Supplementary Meteorological Measurements}

[8] Meteorological variables continuously measured at all three sites included above-canopy downwelling and upwelling solar and longwave radiation (model CNR1, Kipp and Zonen B.V., Delft, The Netherlands), above-canopy downwelling and upwelling photosynthetically active radiation (PAR) (model 190SB, LI-COR Inc.), above- and withincanopy air temperature and relative humidity (model HMP35CF or HMP45CF, Vaisala Oyj, Helsinki, Finland), rainfall (two tipping-bucket rain gauges, model 2, Texas Electronics, Dallas, TX, USA or model 2501, Sierra Misco, Berkeley, CA, USA), soil temperature at the 2, 5, 10, 20 and $50 \mathrm{~cm}$ depths (with copper-constantan thermocouples), soil-heat flux ( 3 heat-flux plates, model F, Middleton 
Instruments, Melbourne, Australia), volumetric soil water content at the depths of $1-2,10-12,35-48$ and $70-100 \mathrm{~cm}$ (with reflectometers model CS-615, Campbell Scientific Inc. (CSI), Logan, UT, USA) at two locations. A precipitation gauge (model I-200B, Geonor A.S., Oslo, Norway) for measuring the liquid-water equivalent of snowfall was installed at HDF00 near the end of 2003.

\subsection{Calculation of Annual Totals, Water Use Efficiency, and Surface Conductance}

[9] The half-hourly turbulent fluxes were calculated using the covariance of the fluctuations in the vertical wind velocity and scalar quantities, namely, air temperature for sensible heat, molar mixing ratio of $\mathrm{CO}_{2}$ for $\mathrm{CO}_{2}$ flux and the molar mixing ratio of water vapor for water vapor flux. The net ecosystem exchange $\left(F_{N E E}\right)$ of $\mathrm{CO}_{2}$ was calculated by adding the turbulent flux of $\mathrm{CO}_{2}$ to the time derivative of the air-column storage of $\mathrm{CO}_{2}$ below the EC sensor level (i.e., the storage flux). In this analysis, the storage flux was calculated following Morgenstern et al. [2004] using the $\mathrm{CO}_{2}$ mixing ratio measured at the EC sensor level. $F_{N E E}$ provides a direct measure of $F_{N E P}$ (i.e., $F_{N E P}=-F_{N E E}$ ). Positive values of $F_{N E P}$ correspond to $\mathrm{C}$ gain by the ecosystem and negative values to C loss. Humphreys et al. [2006] found that average half-hour energy balance closure was $0.80,0.90$ and 0.91 for DF49, HDF88 and HDF00, respectively, for 2002; however, closure corrections were not applied in this analysis.

[10] A common procedure was applied to all sites to fill half-hour data gaps and to obtain annual estimates of $F_{N E P}$ This included filling gaps caused by missing data and created by removing nighttime fluxes when turbulence was not fully developed, i.e., friction velocity $\left(u_{*}\right)$ was less than a threshold value $\left(u_{*} T\right)$. Values of $u_{*}$ of $0.30,0.16$ and $0.08 \mathrm{~m} \mathrm{~s}^{-1}$ were used for DF49, HDF88 and HDF00, respectively [see Morgenstern et al., 2004; Humphreys et al., 2006]. This procedure removed $\sim 60-70 \%$ of the nighttime fluxes at each site. Small gaps (i.e., $<2 \mathrm{~h}$ ) in $F_{N E P}$ were filled by linear interpolation. Measured $R_{e}$ was obtained as $R_{e}=F_{N E E}$ during periods when $P_{g}$ was known to be zero, i.e., during night in the growing season and during night and day in the winter when both air $\left(T_{a}\right)$ and shallow soil $\left(T_{s}\right)$ temperatures were less than $0^{\circ} \mathrm{C}$. An exponential relationship between measured $R_{e}$ and $T_{s}$ at the 2-cm depth for each year was obtained as follows:

$$
\ln R_{e}=A+B T_{s}
$$

This logarithmic transformation of the data minimizes inhomogeneous scatter [Morgenstern et al., 2004] and allows the assumption of normality and homoscedasticity to be valid for linear least squares regression [Humphreys et al., 2005, 2006]. $P_{g}$ was estimated as $F_{N E P}+$ daytime $R_{e}$ (calculated using equation (1) with daytime $T_{S}$ ) and assumed to be zero at night and during periods when both $T_{a}$ and $T_{s}<0^{\circ} \mathrm{C}$. Gaps in $P_{g}$ were filled using the rectangular hyperbolic dependence of $P_{g}$ on $\operatorname{PAR}(Q)$ (Michaelis-Menten light-response equation) given by

$$
P_{g}=\frac{\alpha Q P_{x}}{\alpha Q+P_{x}}
$$

where $\alpha$ is the quantum yield and $P_{x}$ is the photosynthetic capacity $\left(P_{g}\right.$ at light saturation). To account for short-term changes in environmental conditions, a time-varying parameter was determined within a 100-point moving window as the slope of a linear regression, forced through the origin, of the modeled $P_{g}$ (and $R_{e}$ ) versus measured $P_{g}$ (and (and $R_{e}$ ) and was applied as a multiplier to the above relationships [Barr et al., 2004]. Gaps in $F_{N E P}>2$ h were filled using modeled $P_{g}-R_{e}$. Gap-filled values of $F_{N E P}$, $R_{e}$ for both nighttime and daytime, and $P_{g}$ were used to calculate annual totals of $F_{N E P}, R_{e}$, and $P_{g}$. As mentioned above, the $u_{* T}$ criteria removed $60-70 \%$ of the nighttime and hence $30-40 \%$ of the total flux data while the original data (before applying $u * T$ ) loss was $<10 \%$ when using the closed-path IRGA and $20-30 \%$ when using the open-path IRGA (at HDF88). Uncertainties in annual $F_{N E P}$ associated with the random error in half-hourly fluxes and the gap-filling procedure were obtained by resampling half-hourly fluxes after introducing a $20 \%$ random error and also by using Monte Carlo simulation [Griffis et al., 2003; Morgenstern et al., 2004; Krishnan et al., 2006, 2008] by artificially generating gaps (up to $40 \%$ of the total half hours in a year, with continuous gaps varying from a half hour to 10 days) using a uniformly distributed random-number generator. This procedure was repeated 1000 times and the $95 \%$ confidence levels in the annual estimates of $F_{N E P}, P_{g}$ and $R_{e}$ were calculated.

[11] To better understand the physiological response of the ecosystem to changes in soil water content, canopy-level water use efficiency and dry-foliage surface conductance were used. Water use efficiency (WUE), an important indicator of ecosystem function, adaptation and productivity of plants in water-limited areas [Xu and Hsiao, 2004], was calculated as the ratio of daily daytime $\left(Q>200 \mu \mathrm{mol} \mathrm{m}^{-2} \mathrm{~s}^{-1}\right)$ average $P_{g}$ to average evapotranspiration $(E)$, i.e., WUE = $P_{g} / E$. The surface conductance to water vapor transfer $\left(g_{s}\right)$ was calculated by rearranging the Penman-Monteith equation [Monteith and Unsworth, 1990] as given by Krishnan et al. [2006]. The daytime mean value of dry-foliage $g_{s}$ was calculated by averaging daytime $g_{s}$ values for $Q>$ $200 \mu \mathrm{mol} \mathrm{m} \mathrm{m}^{-2} \mathrm{~s}^{-1}$ for those days without precipitation.

\section{Results}

\subsection{Seasonal and Interannual Variations in Environmental Variables}

[12] Figure 1, which shows the annual cycles of monthly total $Q$, rainfall $(R)$ and monthly mean above-canopy air temperature $\left(T_{a}\right)$, soil temperature at the 2-cm depth $\left(T_{s}\right)$, daytime $(Q>0)$ atmospheric saturation deficit $(D)$, average soil water content in the $0-30 \mathrm{~cm}$ layer $(\theta)$ for 2002-2005, indicates that the three sites experienced similar weather with cool and wet winters and dry and warm summers. $Q$ generally peaked during June and July with slightly higher values at HDF88. The variations in $T_{s}$ and $D$ closely followed those in $T_{a}$, all being highest in July and August with the highest values occurring at HDF00 as expected being a recently clear-cut site. However, winters were slightly warmer at HDF88 than at the other two sites. More than $75 \%$ of the annual rainfall occurred between October and March leading to high $\theta$ during these months. The low rainfall rates during May to September resulted in dry 


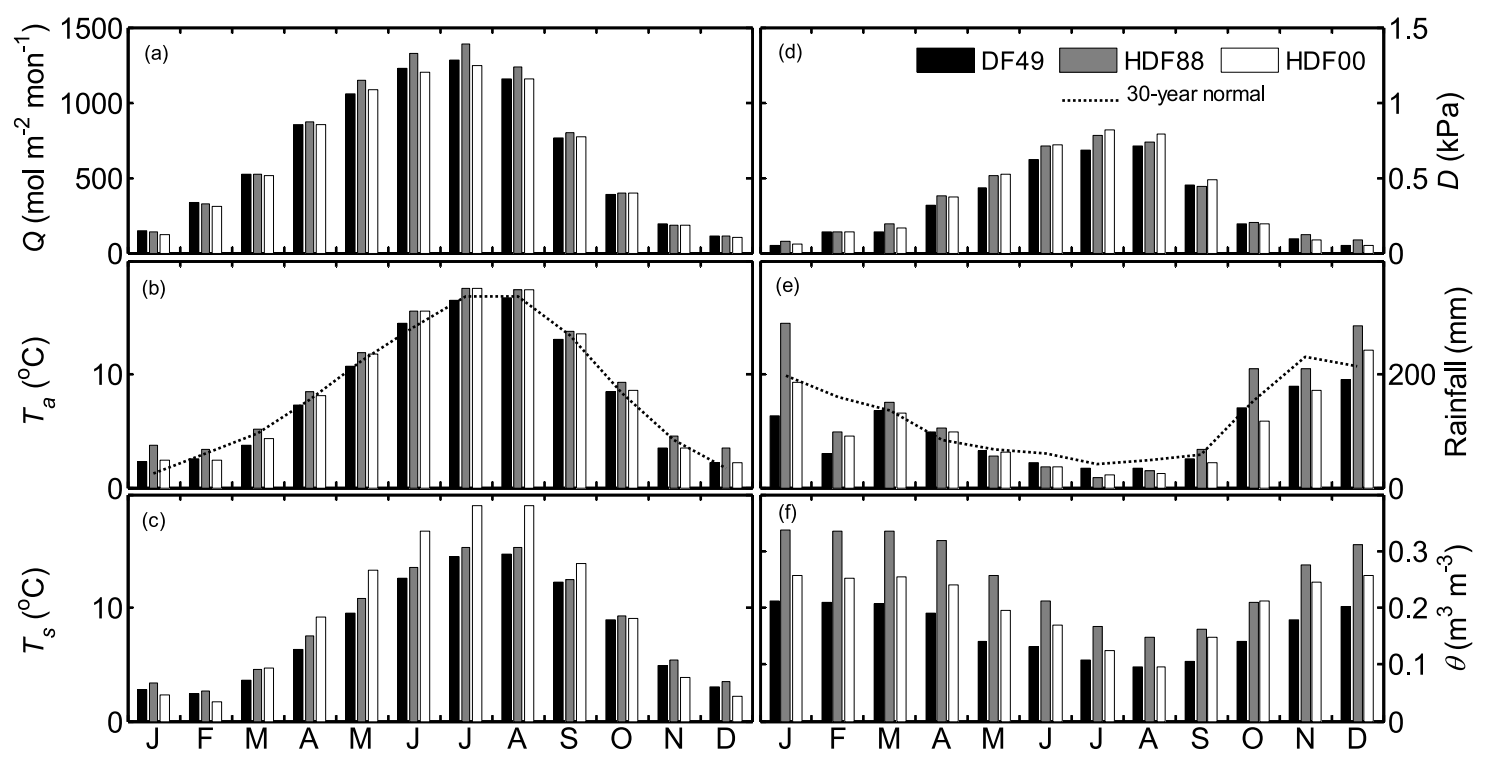

Figure 1. Average monthly values of (a) total downwelling PAR $(Q)$, (b) mean above-canopy air temperature $\left(T_{a}\right)$, (c) mean soil temperature at the 2-cm depth $\left(T_{s}\right)$, (d) mean daytime $(Q>0)$ above-canopy atmospheric saturation deficit $(D)$, (e) total rainfall $(\mathrm{mm})$, and (f) mean soil water content $(\theta)$ in the $0-30 \mathrm{~cm}$ layer for 2002-2006 at DF49, HDF88, and HFD00. The dotted curve represents the 1971-2000 precipitation (snowfall plus rainfall) normals for Campbell River Airport, elevation $105 \mathrm{~m}, 10 \mathrm{~km} \mathrm{NE}$ of DF49. Average monthly snowfall totals (mm liquid-water equivalent) for 2002-2006 were January, 24.3; February, 8.6; March, 27.7; April, 1.0; November, 22.1; December, 19.7.

growing seasons with the lowest $\theta$ values occurring during July to September and August being the driest month at all three sites. $R$ at HDF88 was higher than other sites especially during winter-spring months, but not during growing season. However, $\theta$ at HDF8 8 was generally higher than at the other two sites due to finer textured soil (Table 1).

[13] Interannual variations in annual total $Q\left(Q_{\text {Annual }}\right)$, annual mean above-canopy air temperature $\left(T_{\text {Annual }}\right)$, spring (March to May) mean above-canopy air temperature $\left(T_{\text {Spring }}\right)$, annual total rainfall $\left(R_{\text {Annual }}\right)$ and total MaySeptember rainfall $\left(R_{\text {May-Sept }}\right)$ at DF49, HDF88 and HDF00 are shown in Figure 2. All three sites showed similar interannual variation with HDF88 being somewhat warmer. Based on climate data from the Environment Canada meteorological station at the Campbell River Airport $\left(49^{\circ} 57^{\prime} \mathrm{N}, 125^{\circ} 16.2^{\prime} \mathrm{W}\right.$, elevation $\left.105 \mathrm{~m}\right), 10 \mathrm{~km} \mathrm{NE}$ of DF49, the 1971-2000 mean annual temperature was $8.4^{\circ} \mathrm{C}$ and the mean $R_{\text {Annual }}$ was $1452 \mathrm{~mm}$ (snowfall $109 \mathrm{~mm}$ liquid-water equivalent). ENSO has been identified as a key source of interannual climatic variations for the PNW and has a periodicity of 2-7 years [Rasmussen and Wallace, 1983] whereas PDO fluctuations influence climate on a decadal scale. In the PNW, El Niño events typically occur from October through March or April, and induce mild winters followed by unusually warm springs and dry summers, while La Niña years are generally characterized by wet winters and relatively cool and cloudy conditions in the following spring and summer [Shabbar et al., 1997; Shabbar and Khandekar, 1996]. During the study period from 1998 to 2006, El Niño events occurred in the winters of 1997-1998 (strong), 2002-2003 (medium) and 20062007 (weak) while La Niña events occurred during the winters of 1998-1999 (moderate) and 1999-2000 (strong) (http://www.msc-smc.ec.gc.ca/education/elnino/comparing/ enso1950_2002_e.html).

[14] The impact of El Niño and La Niña events were pronounced in 1998 and 1999 as evident from temperature and $R_{\text {May-Sept }}$. The highest $T_{\text {Annual }}\left(9.1^{\circ} \mathrm{C}\right)$ and second highest spring, summer and autumn temperatures at DF49 occurred in 1998 with dry summer periods as a result of below-normal $R_{\text {May-Sept }}$. The highest $R_{\text {Annual }}$ occurred in 1998. The coldest spring and summer temperatures of the measurement period occurred in 1999 following the La Niña event in the previous winter (1998-1999). The 1999-2000 La Niña event did not significantly influenced temperatures and precipitation at the study sites and 2000 was a normal year in terms of $T_{\text {Spring }}$ and $R_{\text {May-Sept }}$. So was the case with 2001. 2002 experienced the second coldest spring, which resulted from two weeks of cold weather in March. A moderate El Niño event in 2002-2003 had no impact on $T_{\text {Spring }}$ but $R_{\text {May-Sept }}$ was below normal. Of the other neutral years, 2004 and 2005 had warm springs and wetter than normal May-September periods. Summer and April-June temperatures (not shown) at DF49 were highest in 2004, even higher than that in 1998. Even though 2005 was the year with highest $T_{\text {Spring }}\left(8.7^{\circ} \mathrm{C}\right)$, annually, it was a cool year with the third (to 1999 and 2001) coolest summer (June-August) and the lowest $Q$ of the 9 growing seasons. Figure 2 also suggests an increase in $T_{\text {annual }}$ during the study period excluding 1998, the strong El Niño year. All three sites, especially HDF00, had low $R_{\text {May-Sept }}$ in 2003 , a relatively warm year following the moderate El Niño event in 2002. Even though, 2005 had slightly higher $R_{\text {May-Sept }}, Q_{\text {Annual }}$ and $T_{\text {Annual }}$ were lower than those in 2004. 2006 had a normal $T_{\text {Spring }}$ with a below-normal $R_{\text {May-Sept }}$, especially at HDF00. Even though annual rainfall was slightly higher at 


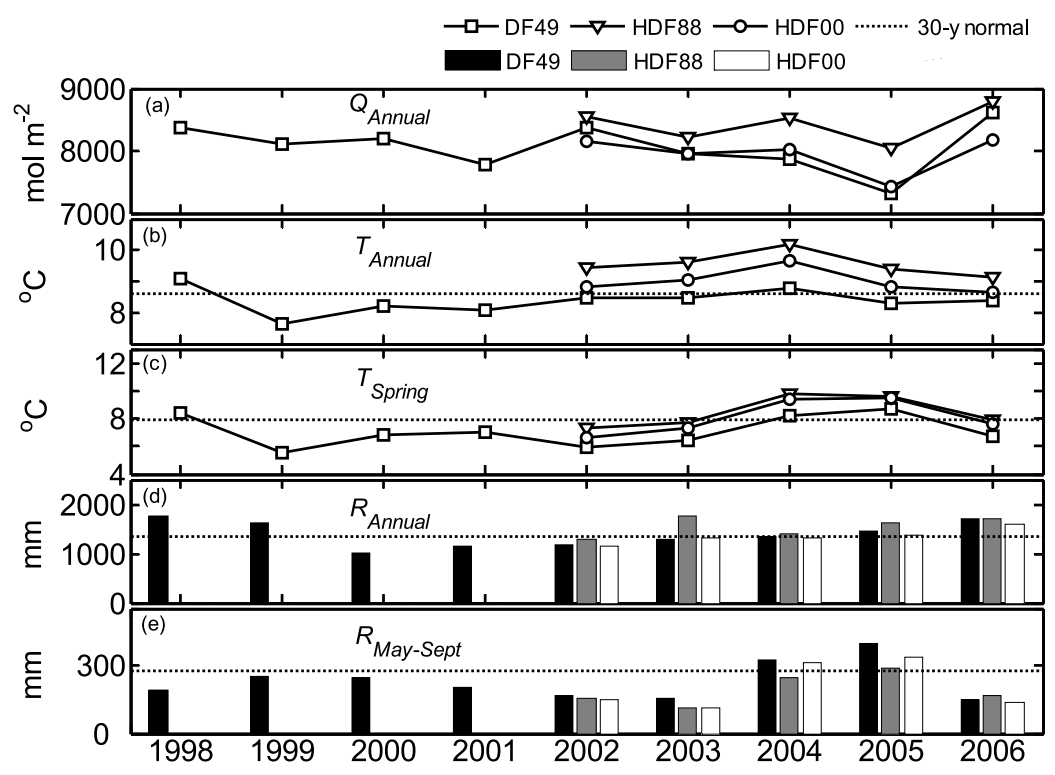

Figure 2. Interannual variations in (a) annual total of PAR $\left(Q_{\text {Annиal }}\right)$, (b) annual mean above-canopy temperature $\left(T_{\text {Annual }}\right)$, (c) spring (March-May) mean above-canopy air temperature $\left(T_{\text {spring }}\right)$, $(\mathrm{d})$ annual total rainfall $\left(R_{\text {Annual }}\right)$, and (e) May-September total rainfall $\left(R_{\text {May-Sept }}\right)$ at DF49, HDF88, and HDF00. The dotted lines represent 1971-2000 climate normals for Campbell River Airport, elevation $105 \mathrm{~m}, 10 \mathrm{~km}$ NE of DF49. At the airport, annual rainfall was 89-97\% of annual precipitation for 1998-2006. Snowfall (liquid-water equivalent) at HDF00 (measured using the Geonor precipitation gauge) and at the airport in 2004 were 43 and $86 \mathrm{~mm}$ and in 2005 were 63 and $52 \mathrm{~mm}$, respectively.

HDF88 during most of the years, $R_{\text {May-Sept }}$ was quite similar in magnitude to values for the other two sites. The results suggest that the main interannual variations in climate at these sites result from variation in $T_{\text {Spring }}$ and summer rainfall rather than annual means of the environmental variables.

\subsection{Interannual Variation in Annual C Fluxes}

\subsubsection{Annual C Fluxes}

[15] The patterns of the interannual variation of $F_{N E P}$ at the three sites were similar during 2002-2006. This was also true for $P_{g}$ and $R_{e}$ (Figure 3). DF49 was a moderate $\mathrm{C}$ sink (mean $\pm \mathrm{SD}=328 \pm 52 \mathrm{~g} \mathrm{C} \mathrm{m}^{-2} \mathrm{yr}^{-1}$ during 2002-2006 and $357 \pm 51$ during 1998-2006) while HDF88 and HDF00, during 2002-2006, were a weak $\mathrm{C}$ source $\left(-64 \pm 75 \mathrm{~g} \mathrm{C} \mathrm{m}^{-2} \mathrm{yr}^{-1}\right)$ and a large $\mathrm{C}$ source $\left(-515 \pm 88 \mathrm{~g} \mathrm{C} \mathrm{m}^{-2} \mathrm{yr}^{-1}\right)$, respectively. The interannual variation of $R_{e}$ at DF49 (1830 \pm 173 during 20022006 and $1767 \pm 147 \mathrm{~g} \mathrm{C} \mathrm{m}^{-2} \mathrm{yr}^{-1}$ during 1998-2006) was greater than that of $P_{g}(2158 \pm 163$ during 20022006 and $2124 \pm 125 \mathrm{~g} \mathrm{C} \mathrm{m}^{-2} \mathrm{yr}^{-1}$ during 1998-2006). For HDF88 and HDF00 during 2002-2006, the interannual variation of $P_{g}\left(1423 \pm 193\right.$ and $781 \pm 226 \mathrm{~g} \mathrm{C} \mathrm{m}^{-2} \mathrm{yr}^{-1}$, respectively) was greater than that in $R_{e}(1487 \pm 147$ and $1297 \pm 185 \mathrm{~g} \mathrm{C} \mathrm{m}^{-2} \mathrm{yr}^{-1}$, respectively), while $P_{g}$ for HDF88 was $642 \mathrm{~g} \mathrm{C} \mathrm{m}^{-2} \mathrm{yr}^{-1}$ greater than that for HDF00 and $R_{e}$ was only $190 \mathrm{~g} \mathrm{C} \mathrm{m}^{-2} \mathrm{yr}^{-1}$ greater (Table 2). HDF88 changed from a weak $\mathrm{C}$ source $\left(-105 \pm 10 \mathrm{~g} \mathrm{C} \mathrm{m}^{-2} \mathrm{yr}^{-1}\right)$ during 2002-2004 to a weak sink $\left(21 \pm 30 \mathrm{~g} \mathrm{C} \mathrm{m}^{-2} \mathrm{yr}^{-1}\right)$ during 2005-2006. As shown in Table 2, intersite differences were greater than interannual variation showing the dominating role of stand age [Humphreys et al., 2006] in determining the magnitude of $F_{N E P}$. Regardless of stand age,

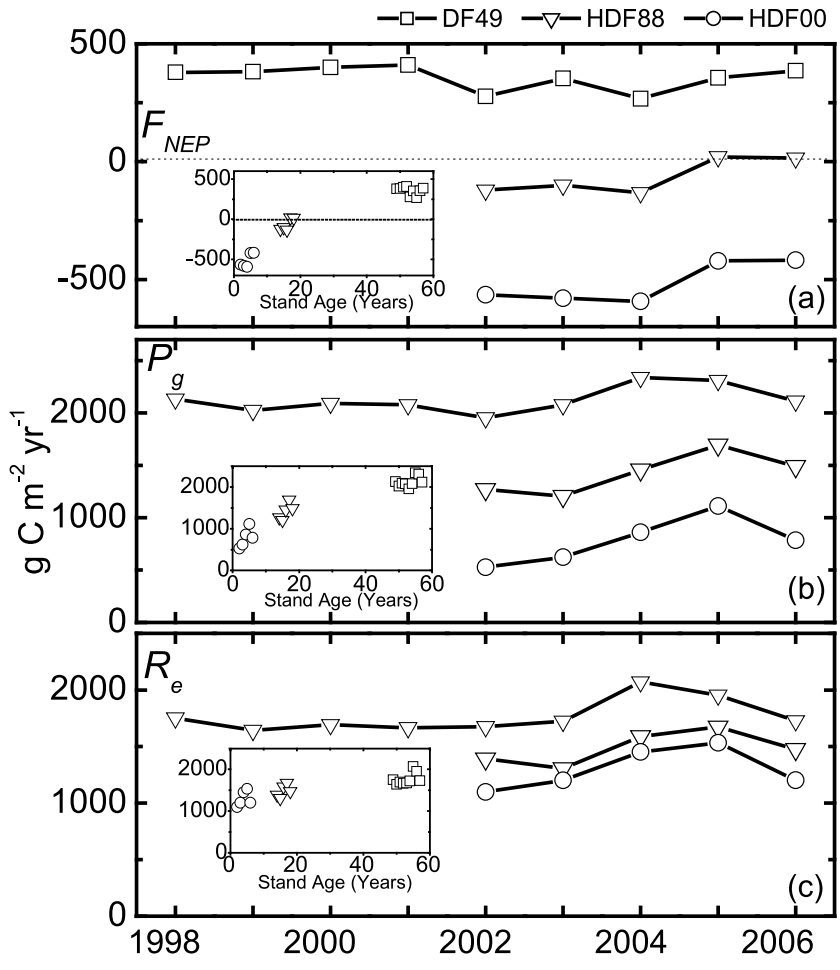

Figure 3. Interannual variation in annual (a) net ecosystem productivity $\left(F_{N E P}\right)$, (b) gross ecosystem photosynthesis $\left(P_{\mathrm{g}}\right)$, and $(\mathrm{c})$ ecosystem respiration $\left(R_{\mathrm{e}}\right)$ at the three sites. The inset in each plot shows relationships of the $F_{N E P}, P_{\mathrm{g}}$, and $R_{\mathrm{e}}$ to stand age. Uncertainty in annual $F_{N E P}$ (see section 2.4) were $\pm 44, \pm 22$, and $\pm 24 \mathrm{~g} \mathrm{C} \mathrm{m}^{-2} \mathrm{yr}^{-1}$ during 1998-2006 at DF49 and 2002-2006 at HDF88 and HDF00, respectively. 
Table 2. Interannual and Intersite Variation of $F_{N E P}, P_{g}$, and $R_{e}$ During 2002-2006

\begin{tabular}{|c|c|c|c|c|}
\hline & $\begin{array}{c}\text { Variable } \\
\left(\mathrm{g} \mathrm{C} \mathrm{m}^{-2} \mathrm{yr}^{-1}\right)\end{array}$ & $\begin{array}{c}\text { Mean } \pm \text { SD } \\
\left(\mathrm{g} \mathrm{C} \mathrm{m}^{-2} \mathrm{yr}^{-1}\right)\end{array}$ & $\begin{array}{c}\text { Range } \\
\left(\mathrm{g} \mathrm{C} \mathrm{m}^{-2} \mathrm{yr}^{-1}\right)\end{array}$ & $\mathrm{CV}^{\mathrm{a}}$ \\
\hline \multicolumn{5}{|c|}{ Interannual Variation $^{\mathrm{b}}$} \\
\hline \multicolumn{5}{|c|}{ 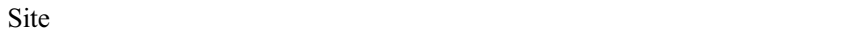 } \\
\hline \multirow[t]{3}{*}{ DF49 } & $F_{N E P}$ & $328 \pm 52$ & 119 & 0.16 \\
\hline & $P_{g}$ & $2158 \pm 163$ & 386 & 0.08 \\
\hline & $R_{e}$ & $1830 \pm 173$ & 396 & 0.09 \\
\hline \multirow[t]{3}{*}{ HDF88 } & $F_{N E P}$ & $-64 \pm 75$ & 153 & 1.18 \\
\hline & $P_{g}$ & $1423 \pm 193$ & 489 & 0.14 \\
\hline & $R_{e}$ & $1487 \pm 148$ & 368 & 0.10 \\
\hline \multirow[t]{3}{*}{ HDF00 } & $F_{N E P}$ & $-516 \pm 88$ & 175 & 0.17 \\
\hline & $P_{g}$ & $781 \pm 226$ & 583 & 0.29 \\
\hline & $R_{e}^{\delta}$ & $1297 \pm 185$ & 435 & 0.14 \\
\hline \multicolumn{5}{|c|}{ Intersite Variation } \\
\hline \multicolumn{5}{|l|}{ Year } \\
\hline 2002 & $F_{N E P}$ & $-136 \pm 421$ & 842 & 3.09 \\
\hline 2003 & & $-109 \pm 467$ & 933 & 4.29 \\
\hline 2004 & & $-153 \pm 430$ & 860 & 2.82 \\
\hline 2005 & & $-15 \pm 389$ & 777 & 25.57 \\
\hline 2006 & & $-6 \pm 402$ & 804 & 68.18 \\
\hline 2002 & $P_{g}$ & $1250 \pm 713$ & 1425 & 0.57 \\
\hline 2003 & & $1302 \pm 733$ & 1456 & 0.56 \\
\hline 2004 & & $1551 \pm 744$ & 1479 & 0.48 \\
\hline 2005 & & $1705 \pm 600$ & 1199 & 0.35 \\
\hline 2006 & & $1462 \pm 665$ & 1329 & 0.45 \\
\hline 2002 & $R_{e}$ & $1389 \pm 289$ & 577 & 0.21 \\
\hline 2003 & & $1411 \pm 277$ & 523 & 0.19 \\
\hline 2004 & & $1704 \pm 325$ & 619 & 0.19 \\
\hline 2005 & & $1721 \pm 215$ & 422 & 0.13 \\
\hline 2006 & & $1468 \pm 262$ & 523 & 0.17 \\
\hline
\end{tabular}

${ }^{\mathrm{a}}$ Coefficient of variation $(\mathrm{CV})$ is calculated as the ratio of standard deviation $(\mathrm{SD})$ to the mean.

${ }^{\mathrm{b}}$ At DF49 1998-2006 mean $\pm \mathrm{SD}$, values of range and CV, were $357 \pm$ 51, 143, and 0.14 for $F_{N E P}, 2124 \pm 125,386$, and 0.06 for $P_{g}$, and $1767 \pm$ 146,429 , and 0.08 for $R_{e}$, respectively.

the general pattern of interannual variations in $F_{N E P}, P_{g}$ and $R_{e}$ were roughly similar suggesting similar responses to environmental variables with few exceptions due to stand age.

[16] In 1998, the warmest year of the record (Figure 2) with a warm spring and dry growing season, both $P_{g}$ and $R_{e}$ at DF49 were higher than for all years except for 2004 and 2005 (Figure 3 ). In 2002, the lowest $P_{g}$ of the record, mainly due to the cold period in March, led to the second lowest value of annual $F_{N E P}$ at DF49. The lowest $F_{N E P}$ values at all three sites were recorded in 2004, the second warmest year for DF49 and the warmest year for HDF88 and HDF00 with a wet and warm growing season. At DF49, $R_{e}$ and $P_{g}$ in 2004 were higher than their 9-year mean by $17 \%$ and $10 \%$, respectively, and were the highest of the record, while $F_{N E P}$ was lower than its 9-year mean by 32\%. 2005 had the second highest $P_{g}$ and $R_{e}$ of the record. At HDF88 and HDF00, $P_{g}, R_{e}$ and $F_{N E P}$ were highest in 2005. In 2006, a cool year with a dry growing season, $R_{e}$ was suppressed more than $P_{g}$ resulting in the third highest $F_{N E P}$ of the record at DF49 and the second highest $F_{N E P}$ at HDF88 and HDF00. $F_{N E P}$ at DF49 was highest during the normal years, 2000 and 2001 (400 and $410 \mathrm{~g} \mathrm{C} \mathrm{m}^{-2} \mathrm{yr}^{-1}$, respectively).

\subsubsection{Climatic Controls of Interannual Variability} of Annual C Fluxes

[17] To obtain better insight into the factors controlling the interannual variability of $\mathrm{C}$ fluxes, a linear regression analysis of the relationship between $\mathrm{C}$ balance components and environmental variables was carried out on monthly and seasonal scales (Tables 3 and 4). The monthly regression analysis suggests that temperature had a positive effect on $P_{g}$ and $R_{e}$ at DF49 until July whereas it had a negative effect on $F_{N E P}$ from May onward. In the latter part of the year, the negative impact of temperature on $F_{N E P}$ was due to the relatively greater increase in $R_{e}$ than in $P_{g}$ with increasing temperature at all three sites. The impact of $\theta$ on $F_{N E P}, P_{g}$ and $R_{e}$ at all sites was most pronounced in August. The interannual variation of seasonal weather, and its control on $\mathrm{C}$ balance components was discernible only for spring (Table 4) and was mainly a result of the effect of $T_{a}$ on $P_{g}$ and $R_{e}$ at all three sites although relationships between $F_{N E P}$ and $T_{\mathrm{a}}$ were not significant. It appears that environmental variables exerted a strong effect on the $C$ balance at half hourly to daily (data not shown) and even monthly timescales. Progressing to the seasonal scale, it was difficult to distinguish the effect except for temperature and to some extent $\theta$.

[18] To examine the influence of $T_{a}$ during the early part of the growing season on the annual $\mathrm{C}$ balance, we carried out linear regression analysis as shown in Figure 4. An increase in $T_{\text {Spring }}$ had a positive effect on annual values of $P_{g}$ and $R_{e}$ at all three sites; however, its effect on annual $F_{N E P}$ was not significant. At DF49, annual $F_{N E P}$ showed a stronger correlation with April to June temperature $(r=$ -0.40 , not shown) than with $T_{\text {Spring }}(r=-0.09)$. Annual $F_{N E P}$ showed a nonsignificant decrease with an increase in summer and autumn temperature at all three sites; however, the correlation was much higher for HDF88 and HDF00 than DF49. As a result, $F_{N E P}$ had a relatively better negative correlation to $T_{\text {Annual }}$ for HDF88 and HDF00 than for DF49. Both $P_{g}$ and $R_{e}$ increased with the $T_{\text {Annual }}$, but the increase was not significant (not shown). The above analysis suggests that annual $F_{N E P}$ at the younger sites was more sensitive to changes in temperature than at DF49.

[19] $R_{\text {May-Sept }}$ had a strong positive effect on $P_{g}$ and $R_{e}$ at all three sites (Figure 5), but its effect on $F_{N E P}$ was negative although not significant. To analyze it further, we examined the response of annual $F_{N E P}, P_{g}$ and $R_{\mathrm{e}}$ to $\theta$ of the $0-30 \mathrm{~cm}$ soil layer. At DF49, annual $F_{N E P}, P_{g}$ and $R_{\mathrm{e}}$ were more dependent on $\theta$ in the latter part of the growing season, mainly August to October. At HDF00, $P_{g}$ and $R_{\mathrm{e}}$ were better correlated with August-October $\theta$ (both positive) than $R_{\text {May-Sept }}$. At HDF88, $P_{g}$ and $R_{\mathrm{e}}$ were only significantly correlated to August $\theta$. The small range of $\theta$ at this site made it difficult to assess its effect, so we carried out an analysis comparing the effect of $\theta$ of the $0-30 \mathrm{~cm}$ soil layer with that of the $0-100 \mathrm{~cm}$ soil layer. At DF49, the $P_{g}$ and $R_{e}$ relationships were similar for both layers but for HDF88, both $P_{g}$ and $R_{e}$ were better correlated to $\theta$ of the $0-30 \mathrm{~cm}$ soil layer.

[20] As shown above, $T_{\text {Spring }}$ and August-October $\theta$ explained most of the variation in $P_{g}$ and $R_{\mathrm{e}}$ at DF49; and, $F_{N E P}$ correlated better to April-June temperature. Therefore, we used the above environmental variables to develop a regression model to explain the effect of climate induced variability on the $\mathrm{C}$ balance at DF49, which is expected to have reached a nearly constant growth rates with little year-to-year change in LAI [Humphreys et al., 2006] and most of the interannual variability attributable to varia- 
tions in climate [Schwalm et al., 2007; Jassal et al., 2008b]. We added March average temperature to account for the significant effect of frost events in late winter-early spring as in 2002 when it markedly reduced $P_{\mathrm{g}}$.

[21] The empirical relations for DF49 (1998-2006) using air temperature and $\theta$ of the $0-30 \mathrm{~cm}$ layer are:

$$
\begin{aligned}
F_{N E P}= & 1295.87-55.73 T_{\text {Apr-Jun }}-5180.68 \theta_{\text {Aug-Oct }}+35 T_{\text {March }}, \\
r^{2} & =0.88, p<0.05 \\
P_{\mathrm{g}}= & 224+82.6 T_{\text {Apr-Jun }}+9791.48 \theta_{\text {Aug-Oct }}+26.68 T_{\text {March }}, \\
r^{2}= & 0.87, p<0.05 \\
R_{e}= & -1071.62+138.35 T_{\text {Apr-Jun }}+14969.94 \theta_{\text {Aug-Oct }} \\
& -8.45 T_{\text {March }}, r^{2}=0.92, p<0.05
\end{aligned}
$$

At the younger sites similar empirical relations using $T_{\text {Spring }}$ and late growing season $\theta$ (Figure 5) were able to explain only $\sim 40 \%$ of the variance in annual $F_{N E P}, P_{g}$ and $R_{\mathrm{e}}$. This was likely the effect of stand age on the annual totals of $F_{N E P}, P_{g}$ and $R_{\mathrm{e}}$ at HDF00 and HDF88 (Figure 3 and Table 2). $F_{N E P}$ at these sites showed a better correlation to $T_{\text {Аnпиа }}$ than at DF49.

\subsection{Seasonal Variation in C Fluxes}

[22] The above analysis shows that the annual $\mathrm{C}$ balance is influenced by stand age and variation in seasonal environmental variables. To better understand ecosystem $C$ exchange dynamics at the three sites, a close inspection of the seasonal fluctuation of $F_{N E P}, P_{g}$ and $R_{\mathrm{e}}$ in relation to environmental variables at the three sites is required.

\subsubsection{Seasonal $\mathbf{C}$ Fluxes}

[23] At DF49, where the annual courses of cumulative $F_{N E P}$ showed a similar pattern for the 9 years, $\mathrm{C}$ gain started in February and continued to the end of July (Figure 6). The maximum rates achieved in March-April varied little among years with the exception of 2002, the year with the cold March. $P_{g}$ generally exceeded $100 \mathrm{~g} \mathrm{C} \mathrm{m}^{-2}$ in March (Figure 7), except in 2002, in response to the increase in $Q$ to values $>500 \mathrm{~mol} \mathrm{~m}^{-2} \mathrm{mon}^{-1}$, while $R_{e}$ in March (Figure 7) generally remained low due to low temperature (Figure 1). This resulted in a marked increase in cumulative $F_{N E P}$ early in the growing season. The interannual differences in $\mathrm{C}$ sequestration became visible mainly from May onward (Figure 6). During May-June, $R_{e}$ increased substantially with the increase in temperature (Figure 1) and served to offset the high values of $P_{g}$ resulting in a decrease in monthly $F_{N E P}$ from May to July. From August to October, $F_{N E P}$ was close to zero resulting in almost no change in cumulative $F_{N E P}$. In 2004, a year with a warm spring and wet growing season, $F_{N E P}$ was close to zero or slightly negative from August to October resulting in the lowest annual $F_{N E P}$ of the record. Similar variations were observed at HDF88 in 2004.

[24] In contrast to the interannual variations in cumulative $F_{N E P}$ for DF49, cumulative $F_{N E P}$ at HDF88 early in the year increased each year as stand age increased. However, interannual differences in $F_{N E P}$ observed early in the year changed in the latter part of the growing season (Figure 6). A remarkable increase in cumulative $F_{N E P}$ began in early April of 2005 and 2006 compared with the previous years. This $\mathrm{C}$ gain eventually helped HDF88 to slightly exceed C neutrality (i.e., $F_{N E P}=0$ annually) by the end of these two 
Table 4. Results of the Linear Regression Analysis $(y=b x+c)$ of Seasonal Total C Fluxes to Seasonal Mean Environmental Variables ${ }^{\mathrm{a}}$

\begin{tabular}{|c|c|c|c|c|c|}
\hline$y$ Variable & Site & Winter (DJF) & Spring (MAM) & Summer (JJA) & Autumn (SON) \\
\hline \multirow[t]{2}{*}{$F_{N E P}$} & DF49 & & & & \\
\hline & $\begin{array}{l}\text { HDF } 88 \\
\text { HDF00 }\end{array}$ & $\begin{array}{l}-\boldsymbol{T}_{\boldsymbol{s}},-\theta,\left(-T_{a}\right) \\
-T_{a}\end{array}$ & $\begin{array}{l}(-\theta) \\
-\theta, D,\left(T_{a}\right)\end{array}$ & $\begin{array}{l}-\boldsymbol{T}_{\boldsymbol{a}},(\theta),(-D) \\
\left(-T_{a}\right),\left(-T_{s}\right),(-D)\end{array}$ & $-\boldsymbol{T}_{s},-\boldsymbol{\theta},(Q)$ \\
\hline \multirow{3}{*}{$P_{g}$} & DF49 & & $\boldsymbol{T}_{\boldsymbol{a}}, \boldsymbol{T}_{\boldsymbol{s}}, \boldsymbol{D},(-\theta)$ & $\left(T_{s}\right)$ & $-T_{s}$ \\
\hline & HDF88 & $-\boldsymbol{T}_{\boldsymbol{s}},(-\theta)$ & $T_{a},\left(T_{s}\right)$ & $-\boldsymbol{Q},-\boldsymbol{D}, \theta,\left(-T_{a}\right)$ & $-Q,-D,\left(-T_{a}\right)$ \\
\hline & HDF00 & & $\boldsymbol{T}_{\boldsymbol{a}}, T_{S}$ & $\theta,-Q,(-D)$ & $(\theta)$ \\
\hline \multirow[t]{3}{*}{$R_{e}$} & DF49 & & $\boldsymbol{T}_{\boldsymbol{a}}, \boldsymbol{T}_{\boldsymbol{s}},(-\theta)$ & $\left(T_{s}\right)$ & $\left(T_{s}\right)$ \\
\hline & HDF88 & $\boldsymbol{T}_{\boldsymbol{a}}, \boldsymbol{T}_{\boldsymbol{s}}, \theta$ & $T_{a}, T_{s}$ & & $T_{s}$ \\
\hline & HDF00 & $\left(T_{a}\right)$ & $\boldsymbol{T}_{\boldsymbol{a}}, T_{s}$ & $\theta$ & $\left(\theta_{s}\right)$ \\
\hline
\end{tabular}

${ }^{\mathrm{a}}$ Here $y$ is the independent variable $\left(F_{N E P}, P_{g}\right.$, and $\left.R_{e}\right)$, and $x$ is the dependent variable $\left(T_{a}, T_{s}, \theta\right.$, and $\left.D\right)$. The bold letters indicate the $x$ variables with highly significant relations with the $y$ variable $(p<0.05)$, nonbold letters indicate relationships with $0.1<p>0.05$, and letters given in parentheses are for relations with $0.2<p>0.1$. Relations with $p>0.2$ are not shown here. Negative signs indicate negative correlations.

years. The relatively high loss of $\mathrm{CO}_{2}$ during most of the year resulted in HDF00 being a strong $\mathrm{C}$ source. However, the positive changes in $F_{N E P}$ during June to August 2005 and 2006 resulted in an increase in annual $F_{N E P}$ of $150 \mathrm{~g} \mathrm{C} \mathrm{m}^{-2}$, similar to those for HDF88 in these two years. While DF49 and HDF88 had significant photosynthesis throughout most of the year, $P_{g}$ at HDF00 was significant only during April to October (Figure 7). During the peak growing season, monthly total $R_{e}$ at DF49 was $\sim 100 \mathrm{~g} \mathrm{C} \mathrm{m}^{-2}$ higher than that at HFD88 or HDF00. During January to March and October to December, $R_{e}$ values at HDF00 were similar to those at DF49 while at HDF88 they were higher than at

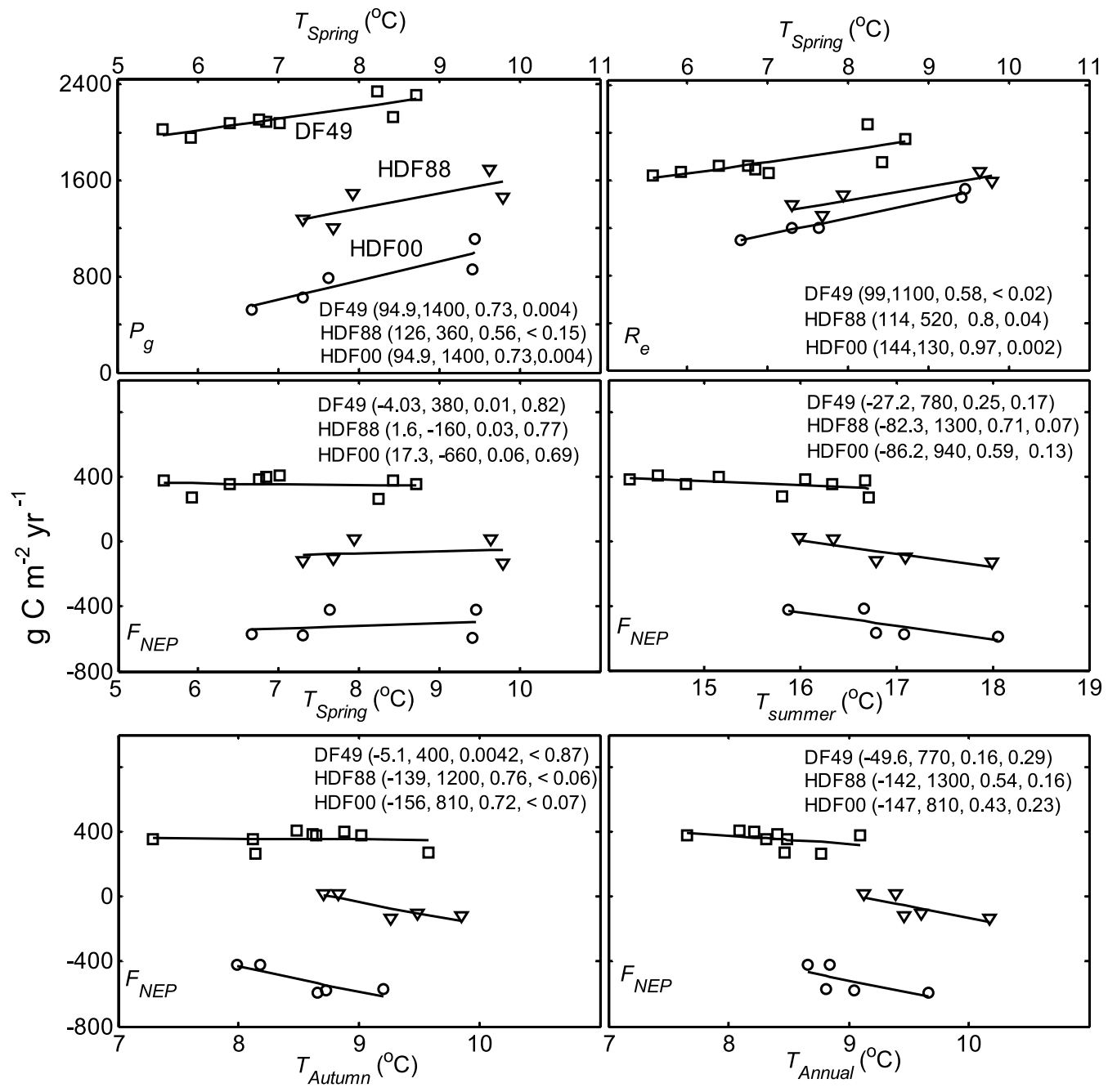

Figure 4. Annual gross ecosystem photosynthesis $\left(P_{\mathrm{g}}\right)$ and ecosystem respiration $\left(R_{\mathrm{e}}\right)$ at the three sites as a function of spring temperature, and net ecosystem productivity $\left(F_{N E P}\right)$, as a function of spring, summer, autumn, and annual mean air temperature. The numbers in parenthesis are values of slope, intercept, $r^{2}$, and $p$ for the respective regression relations. 

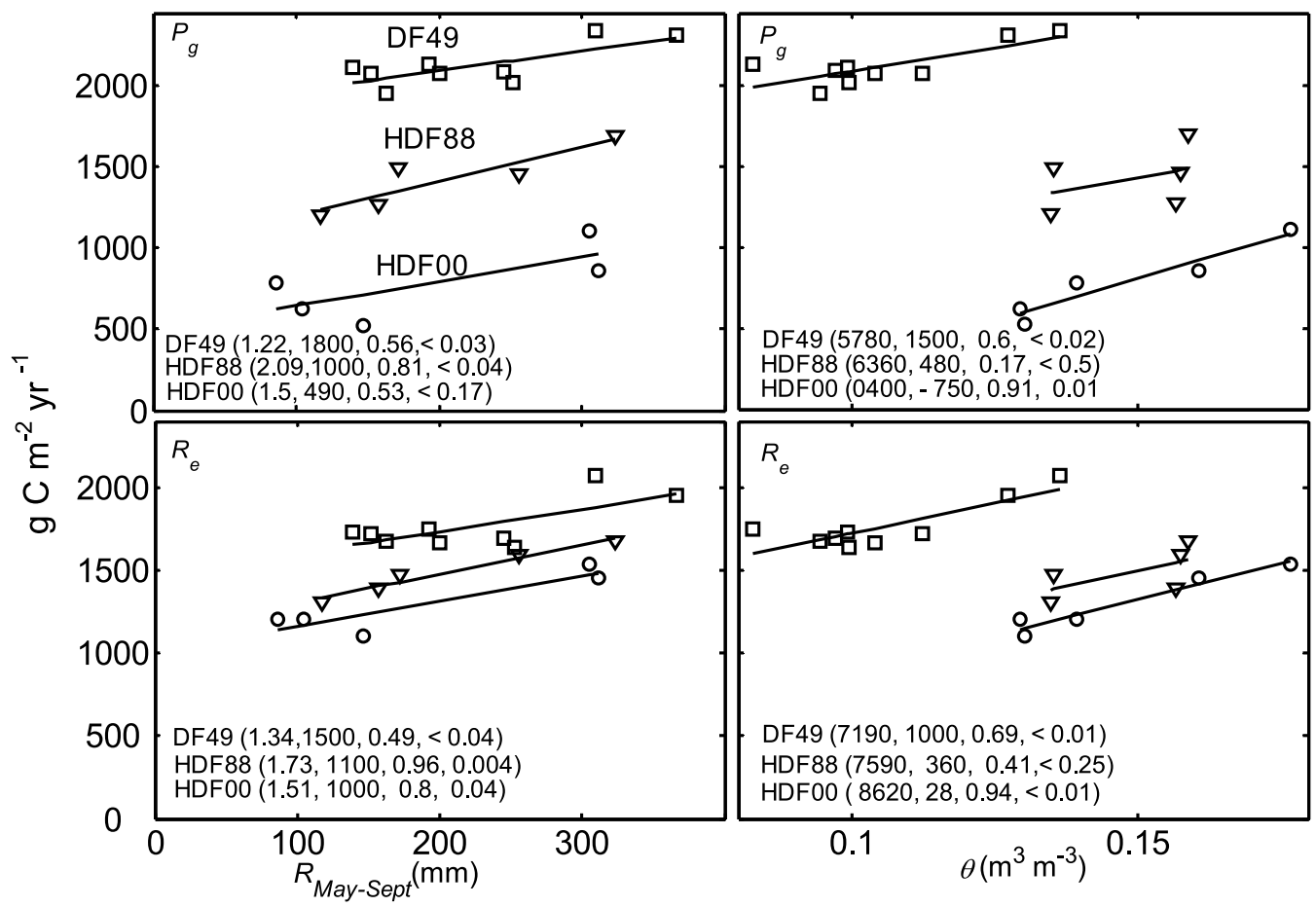

Figure 5. Annual gross ecosystem photosynthesis $\left(P_{\mathrm{g}}\right)$ and ecosystem respiration $\left(R_{\mathrm{e}}\right)$ at the three sites as a function of May-September rainfall and August-October $0-30 \mathrm{~cm}$ soil water content $(\theta)$, for DF49, HDF88, and HDF00, respectively. The relationships of annual net ecosystem productivity $\left(F_{N E P}\right)$ to rainfall and $\theta$ were not significant. The numbers in parenthesis are values of slope, intercept, $r^{2}$, and $p$ for the respective regression relations.

the other two sites. Wintertime $R_{e}$ was nearly equal to soil respiration [Jassal et al., 2007, 2008a].

\subsubsection{Effect of Seasonal Changes in Environmental Variables on the $\mathrm{C}$ Balance}

[25] To examine the seasonal response of the $\mathrm{C}$ balance components to changes in $T_{a}, \theta$, and to aid in our interpretation of annual $F_{N E P}$, the time series of 5-day running averages of $T_{a}, \theta, F_{N E P}, P_{g}, R_{e}$ and $E$ during 1998 (for DF49 only), and 2004, 2005 and 2006 (for all 3 sites) are shown in Figure 8 . These years were chosen because

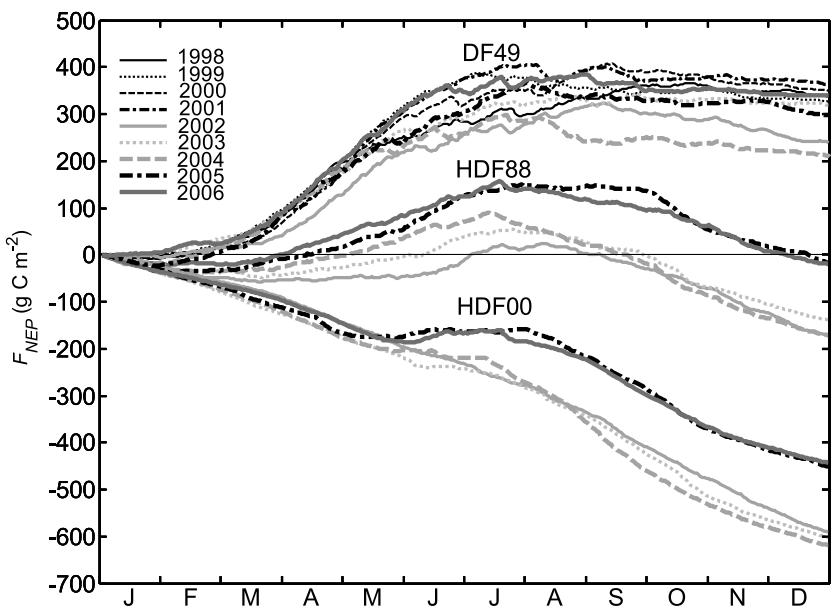

Figure 6. Annual cycles of cumulative $F_{N E P}$ at DF49, HDF88, and HDF00.
2004 and 2005 were years with a warm spring and a wet growing season whereas 2006 was a year with a normal spring with a warm and dry growing season. 1998 is included to show the pattern during a year with a warm spring, like 2004 and 2005, but with a warm and dry growing season. The main difference between 2004 and 2005 was the precipitation distribution and the variation in $\theta$ during

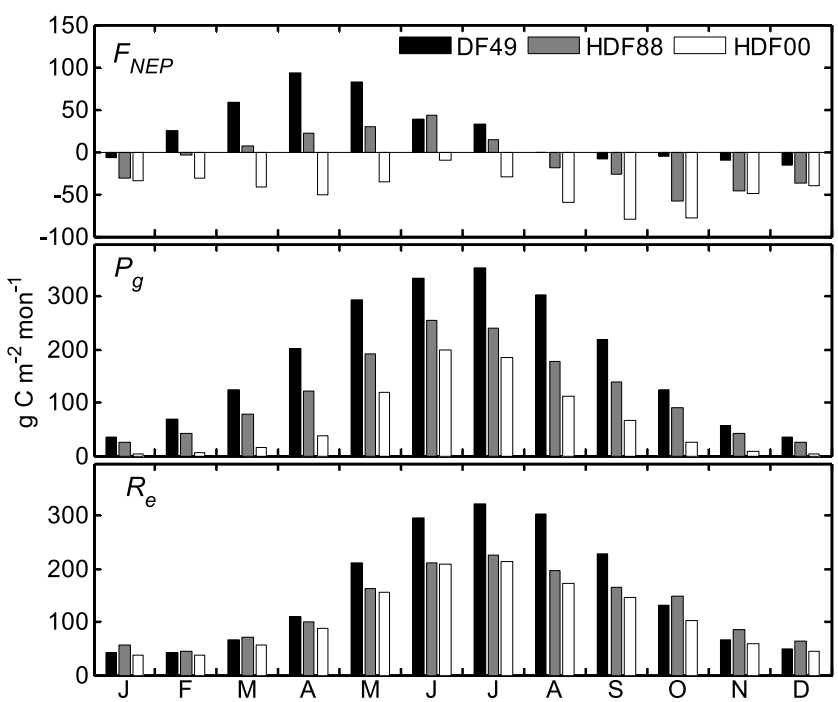

Figure 7. The 2002-2006 mean monthly $F_{N E P}, P_{\mathrm{g}}$, and $R_{\mathrm{e}}$ at DF49, HDF88, and HDF00. 


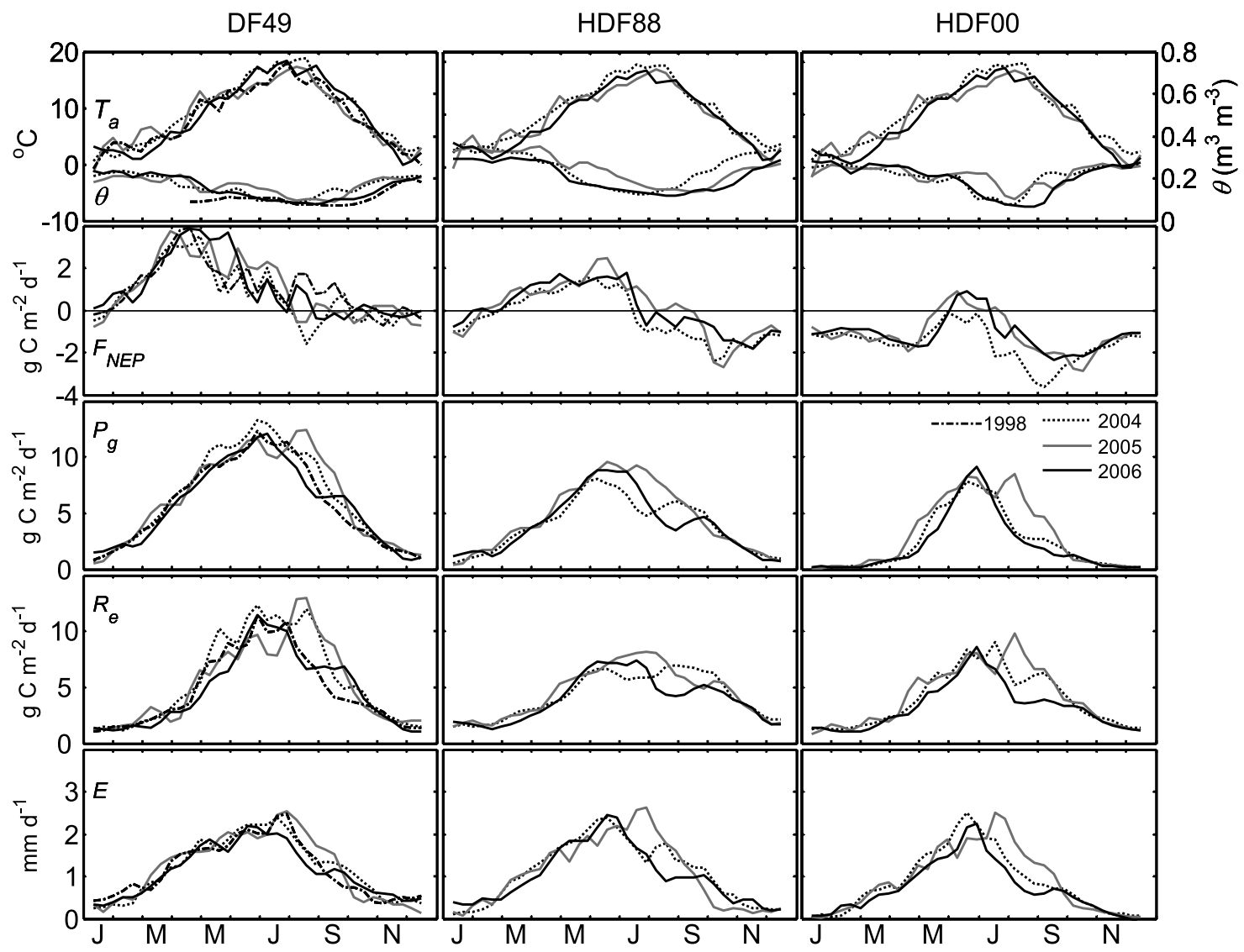

Figure 8. Five-day running mean of air temperature $\left(T_{a}\right)$, soil water content $(\theta)$ in the $0-30 \mathrm{~cm}$ layer, $F_{N E P}, P_{\mathrm{g}}$, and $R_{\mathrm{e}}$ during 2004-2006 at DF49, HDF88, and HDF00. The years 2004 and 2005 were years with a warm spring and a wet growing season whereas 2006 was a year with a normal spring with a dry growing season. The year 1998 is included to show the pattern during a year with a warm spring, like 2004 and 2005, but with a warm and dry growing season. Of the 4 years, 2005 had the coldest growing season. Values of annual $E$ for 2004-2006 were 420, 429, and $398 \mathrm{~mm}$ at DF49 (418 mm for 1998), 387, 382 , and $361 \mathrm{~mm}$ at HDF88, and 302,316 , and $253 \mathrm{~mm}$ at HDF00. Annual $\mathrm{C}$ fluxes $\left(\mathrm{g} \mathrm{C} \mathrm{m}^{-2}\right)$ at DF49 for 1998, 2004-2006 were 379, 267, 355, and 386 for $F_{N E P}, 2131,2338,2310$, and 2112 for $P_{g}$, and1752, 2071, 1955, and 1726 for $R_{e}$, respectively. The annual C fluxes at HDF88 for 2004-2006 were -132, 20 and 15 for $F_{N E P}, 1457,1694$, and 1490 for $P_{g}$, and 1589, 1694, and 1475 for $R_{e}$, respectively, and at HDF00, annual values were $-593,-421$, and -418 for $F_{N E P}, 859,1111$, and 784 for $P_{g}, 1452,1533$, and 1204 for $R_{e}$, respectively.

the growing season. 2004 had a dry early growing season and a wet late growing season whereas 2005 had a wet early growing season while the rest of the growing season was relatively dry. $E$ is shown here because of the close relationship between the $\mathrm{CO}_{2}$ and water vapor exchange processes. This coupled dependence is further examined using parameters describing physiological responses of the ecosystem, namely, canopy level $g_{s}$ and WUE as shown in Figure 9. At all the three sites, $P_{g}$ was highly correlated to $E\left(P_{g}\left(\mathrm{~g} \mathrm{C} \mathrm{m}^{-2} \mathrm{mon}^{-1}\right)=5.78 E\left(\mathrm{~mm} \mathrm{mon}^{-1}\right)+9.6, r^{2}=0.97\right.$, $P_{g}=3.25 E+18, r^{2}=0.86$ and $P_{g}=3.68 E-14, r^{2}=0.91$ for DF49 (1998-2006), HDF88 (2002-2006) and HDF00 (2002-2006), respectively). $F_{N E P}, P_{g}$ and $R_{e}$ values were highest at DF49. Even though peak $F_{N E P}$ was lowest at HDF00, magnitudes of $P_{g}$ and $R_{e}$ at HDF00 were higher than those at HDF88 during some part of growing season in 2004, 2005 and 2006. Furthermore, the number of days when daily $F_{N E P}>0$ (C sink) was higher at DF49 than at the other two sites $(233 \pm 15,167 \pm 19,42 \pm 14$ days for
DF49, HDF88 and HDF00, respectively, during 2004, 2005 and 2006). Maximum daily $E$ at all three sites reached a value of $2.5 \mathrm{~mm} \mathrm{~d}^{-1}$ indicating a relatively conservative response to stand age.

[26] In 1998, even though $P_{g}, R_{e}$ and $E$ increased in response to the relatively warmer than normal February to May temperature, the relatively dry conditions during the growing season, especially in August and September, suppressed $P_{g}, R_{e}, E$ and $g_{s}$. The greater decrease in $R_{e}$ than $P_{g}$ in August and September resulted in an increase in $F_{N E P}$. In 2004, the year with second warmest spring and a warm growing season with the warmest August, the values of $\theta$ up to July at all the three sites were similar to those of 2006, which had low $R_{\text {May-Sept }}$ (Figure 8). The dry conditions in early summer had no effect on $P_{g}$ and $R_{e}$ at DF49, with both being higher than in other years. At HDF88 on the other hand, the dry conditions during May end to July resulted in low values of $P_{\mathrm{g}}, R_{e}$, and $g_{s}$. In August of 2004, the increase in $\theta$ increased $R_{e}$ more than $P_{g}$ leading to the lowest values 

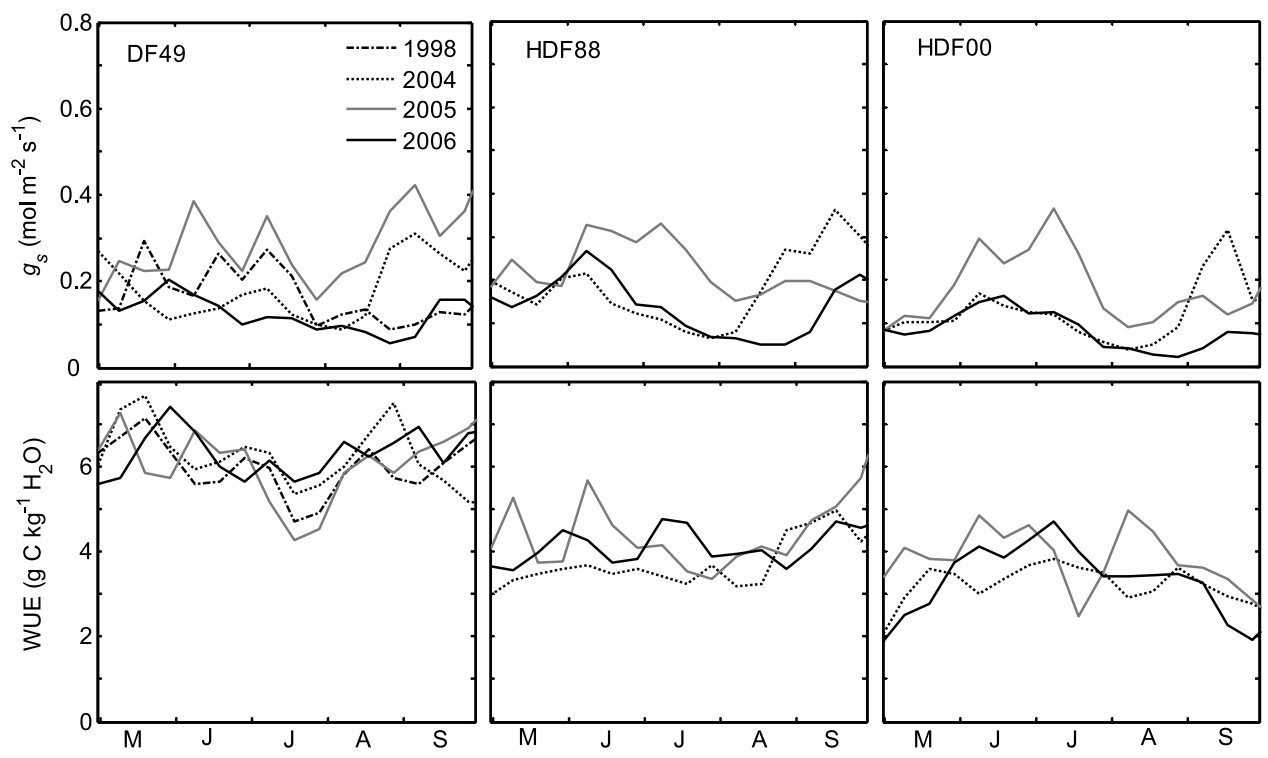

Figure 9. Five-day running mean of dry-foliage surface conductance $\left(g_{s}\right)$ and water use efficiency (WUE) at DF49, HDF88, and HDF00 during May-September for the years considered in Figure 8. Mean May-September WUE values at DF49 for 1998-2006 were 5.95, 5.95, 5.76, 6.43, 5.94, 6.48, 6.29, 6.01, and $6.33 \mathrm{~g} \mathrm{C} \mathrm{kg}^{-1} \mathrm{H}_{2} \mathrm{O}$, and at $\mathrm{HDF} 88$ for 2002-2006 values were $3.24,3.21,3.74,4.37$, and $4.13 \mathrm{~g} \mathrm{C} \mathrm{kg}^{-1}$ $\mathrm{H}_{2} \mathrm{O}$, and at $\mathrm{HDF} 00$ for 2002-2006 values were 2.42, 3.00, 3.30, 3.89, and $3.40 \mathrm{~g} \mathrm{C} \mathrm{kg}^{-1} \mathrm{H}_{2} \mathrm{O}$, respectively.

of $F_{N E P}$ for the four years at all the three sites. The warmer than normal spring in 2005 followed by a relatively cool summer, favored $P_{g}$ and $g_{\mathrm{s}}$ at all three sites leading to an increase in $F_{N E P}$ during the early part of the growing season with very discernible effects at the younger sites. Wetter growing conditions from June to September resulted in higher than normal $P_{g}, R_{e}, E$ and $g_{s}$ at all three sites, especially the younger sites. The cool and wet summer in 2005 suppressed annual $R_{e}$ more than $P_{g}$ resulting in an increase in annual $F_{N E P}$ over that in 2004 (Figure 3). This effect on $P_{g}$ was more pronounced at the younger sites resulting in the highest annual values of $P_{g}$ and $F_{N E P}$ of the record. The dry growing season in 2006, a year with normal $T_{\text {Spring }}$, led to an increase in $F_{N E P}$ at DF49 due to the relatively larger decrease in $R_{e}$ than $P_{g}$ in response to the dry conditions. At the younger sites, the dry conditions in the latter part of the growing season decreased $P_{g}$ more than $R_{e}$ resulting in low $F_{N E P}$ during September and October and slightly lower annual $F_{N E P}$ values than those in 2005 . However, in a comparison of $\mathrm{C}$ fluxes at HDF88 for the years 2005 and 2006, Jassal et al. [2008a] found that the late summer-early fall (August-October) drought in 2006 resulted a greater decrease in $R_{e}$ than in $P_{g}$ leading to an increase in $F_{N E P}$ over the same period in 2005 .

\subsubsection{Response of Canopy Level Physiological Parameters}

[27] Both WUE and $g_{s}$ at these sites have been reported to decrease in response to increasing $D$ at hourly timescales [Ponton et al., 2006; Humphreys et al., 2003]. As shown in Figure 1, $D$ reached its highest values in August, the driest month at all three sites. Results indicated that high $D$ and dry soil water conditions had a strong negative effect on $P_{g}$ (Figure 8). The differences in the magnitude of $g_{s}$ with high values at DF49 and low values at HDF00 were as expected considering the ages of the stands and low LAI at HDF00
[Kelliher et al., 1993] (Figure 9). $g_{s}$ values at all the three sites were lowest during July and August, the period with lowest $\theta$ and highest $D$. The lowest values of $g_{s}$ occurred in 2006 due to its dry and warm weather. The changes in $g_{s}$ at these sites closely followed the changes in $\theta$ shown in Figure 8. For example, the increase in $\theta$ in mid-August 2004 increased $g_{s}, P_{g}$ and $R_{e}$ at all three sites. Time series of WUE (Figure 9) show that during May to September, it was slightly higher at HDF88 than at HDF00. At HDF88, mean May-September WUE increased from 3.2 to $4.4 \mathrm{~g} \mathrm{C} \mathrm{kg}^{-1}$ water and at HDF00 2.4 to $3.9 \mathrm{~g} \mathrm{C} \mathrm{kg}^{-1}$ water from 2002 to 2005. At the two younger sites, WUE was lower in 2006. At DF49, WUE in July 2006 was slightly higher than that in 2005. The interannual $(1998-2006)$ variability in mean May-September WUE at DF49 was less than $4 \%$ of the mean $\left(6.12 \pm 0.24 \mathrm{~g} \mathrm{C} \mathrm{kg}^{-1} \mathrm{H}_{2} \mathrm{O}\right)$ whereas at the younger sites it was more than $15 \%$ of the mean $(3.21 \pm 0.54$ and $3.74 \pm 0.52 \mathrm{~g} \mathrm{C} \mathrm{kg}^{-1} \mathrm{H}_{2} \mathrm{O}$ at HDF00 and HDF88, respectively) likely due to their young age and less developed root systems. The small variation in WUE at DF49 indicates that it is a relatively conservative quantity. In general, WUE at HDF00 was low in May and September and reached almost a steady value in July and August. Similar values of WUE during the peak growing season at all three sites irrespective of changes in $\theta$ between the years suggest strong coupling of $\mathrm{CO}_{2}$ and water vapor exchange processes at these sites.

3.3.4. Response of $\boldsymbol{P}_{g}$ and $\boldsymbol{R}_{\boldsymbol{e}}$ to Wet and Dry Conditions [28] In order to examine the responses of $P_{g}$ and $R_{e}$ to wet and dry conditions, we examined the response of daytime $P_{g}$ to $Q$ and nighttime $R_{e}$ to $T_{s}$ at the 2-cm depth during May to September for wet and dry conditions as shown in Figure 10. The parameters of the equations obtained from the regression analysis (equation (1) for $R_{e}$ and equation (2) for $P_{g}$ ) during dry and wet conditions are shown in Table 5. 

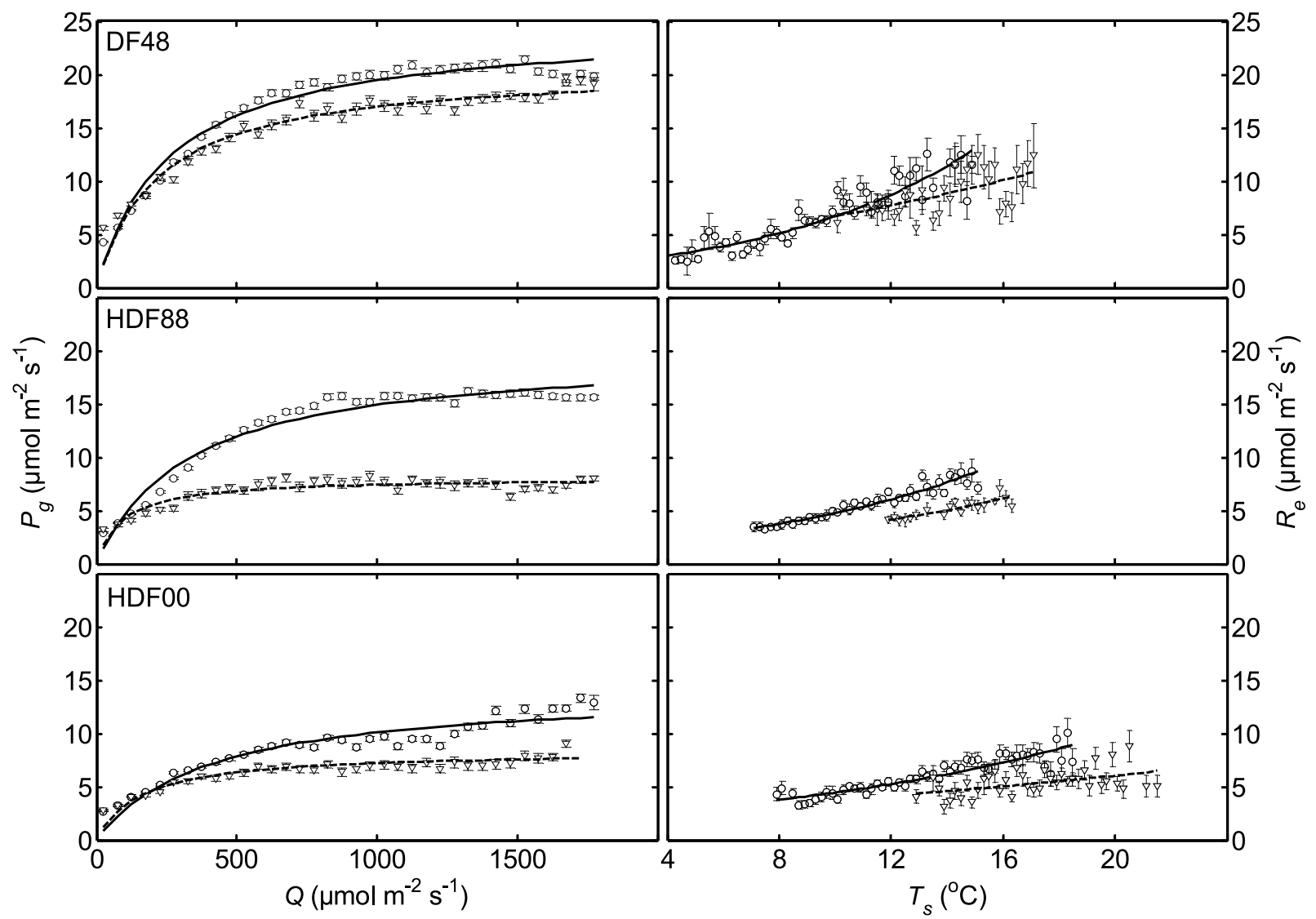

Figure 10. Influence of wet (circles) and dry (triangles) conditions on the response of $P_{g}$ to $Q$, and $R_{e}$ to $T_{s}$ at the 2-cm depth. Here wet conditions refer to $\mathrm{s} \theta_{R}>0.40$ in the $0-30 \mathrm{~cm}$ soil layer, and dry conditions refer to $\theta_{\mathrm{R}}<0.20$ in the $0-30 \mathrm{~cm}$ soil layer. Symbols in Figure 10 (left) represent binned $P_{g}$ using bin width of $50 \mu \mathrm{mol} \mathrm{m} \mathrm{m}^{-2} \mathrm{~s}^{-1}$, and symbols in Figure 10 (right) represent $R_{e}$ using bin widths of $0.2^{\circ} \mathrm{C}$. Vertical bars represent standard deviations in each bin. Parameters for the fitted curves (solid lines for $\theta_{R}>0.40$ and dashed lines for $\theta_{R}<0.20$ ) are in Table 5 .

Here 'wet conditions' refers to periods when relative available water content $\left(\theta_{R}\right)$ in the $0-30 \mathrm{~cm}$ soil layer was $>0.40$ and 'dry conditions' refers to periods when it was $<0.20 . \theta_{R}$ is defined as $\left(\theta-\theta_{W P}\right) /\left(\theta_{F C}-\theta_{W P}\right)$, where $\theta_{F C}$ and $\theta_{W P}$ are $\theta$ at field capacity (soil water matric potential = $-10 \mathrm{kPa}$ ) and the wilting point (matric potential $=-1.5 \mathrm{MPa}$ ), respectively. $\theta_{F C}$ and $\theta_{W P}$ were 0.24 and $0.11 \mathrm{~m}^{3} \mathrm{~m}^{-3}$ at HDF88 [Jassal et al., 2008a], 0.21 and $0.06 \mathrm{~m}^{3} \mathrm{~m}^{-3}$ at DF49 and 0.24 and $0.11 \mathrm{~m}^{3} \mathrm{~m}^{-3}$ at HDF00 [Humphreys et al.,
2006], respectively. Periods with $\theta_{R}<0.40$ have been reported to cause noticeable drought stress to plants [Campbell and Norman, 1998; Krishnan et al., 2006].

[29] During dry conditions both $P_{g}$ and $R_{e}$ at all the three sites showed a decreased sensitivity to $Q$ and $T_{s}$, respectively. The impact of dry conditions on the response of $P_{g}$ to $Q$ was less pronounced at DF49 than HDF00 and HDF 88 . Photosynthetic capacity in dry conditions decreased by $18 \%, 59 \%$ and $44 \%$ from their values in wet conditions

Table 5. Parameters of Equations (1) and (2) Describing the May-September Relationships Between $R_{e}$ and $T_{s}$ at the 2-cm Depth, and $P_{g}$ and $Q$ for Dry and Moist Conditions ${ }^{\mathrm{a}}$

\begin{tabular}{|c|c|c|c|c|c|c|c|c|c|}
\hline Site & Soil Condition & $A$ & $\begin{array}{c}B \\
\left(\mathrm{~K}^{-1}\right)\end{array}$ & $Q_{10}$ & $\begin{array}{c}R_{10} \\
\left(\mu \mathrm{mol} \mathrm{m}{ }^{-2} \mathrm{~s}^{-1}\right)\end{array}$ & $r^{2}$ & $\begin{array}{c}\alpha \\
\text { (mol CO} \\
\text { mol }^{-1} \text { photons) }\end{array}$ & $\begin{array}{c}P_{\max } \\
\left(\mu \mathrm{mol} \mathrm{m} \mathrm{m}^{-2} \mathrm{~s}^{-1}\right)\end{array}$ & $r^{2}$ \\
\hline \multirow[t]{2}{*}{ DF49 } & moist & 0.134 & 0.562 & 3.8 & 6.7 & 0.92 & 0.09 & 24.47 & 0.96 \\
\hline & dry & 0.067 & 1.234 & 1.9 & 6.8 & 0.60 & 0.09 & 20.7 & 0.94 \\
\hline \multirow{2}{*}{ HDF88 } & moist & 0.118 & 0.381 & 3.3 & 4.8 & 0.97 & 0.06 & 19.84 & 0.96 \\
\hline & dry & 0.096 & 0.278 & 2.6 & 3.4 & 0.88 & 0.08 & 8.08 & 0.85 \\
\hline \multirow[t]{2}{*}{ HDF00 } & moist & 0.081 & 0.682 & 2.0 & 4.5 & 0.92 & 0.03 & 14.15 & 0.90 \\
\hline & dry & 0.046 & 0.879 & 1.6 & 3.8 & 0.50 & 0.06 & 7.94 & 0.87 \\
\hline
\end{tabular}

${ }^{\mathrm{a}}$ See Figure 8. Temperature coefficient of ecosystem respiration, $Q_{10}=\exp (10 B)$, and ecosystem respiration at a reference temperature of $10^{\circ} \mathrm{C}$, $R_{10}=Q_{10} \exp A$. All relationships are significant at $p<0.05$. Moist conditions refer to periods when $\theta_{R}>0.4$, and dry conditions refer to periods when $\theta_{R}<0.2$. $\theta_{R}$ is the relative available water content in the $0-30 \mathrm{~cm}$ layer (see text). 
at DF49, HDF88 and HDF00, respectively. Changes in the response of $R_{e}$ to $T_{s}$ under dry conditions occurred for $T_{s}>11^{\circ} \mathrm{C}$ (Figure 10). Even though $Q_{10}$ values decreased by $50 \%$ from those in wet conditions at DF49, $R_{10}$ increased slightly. $R_{10}$ at HDF88 and HDF00 decreased by $21 \%$ and $20 \%$, respectively, whereas $Q_{10}$ decreased by $29 \%$ and $16 \%$ at HDF88 and HDF00, respectively. For the same range of soil temperature $\left(12-14^{\circ} \mathrm{C}\right)$ during July-September, the driest part of the growing season, mean $R_{e}$ during dry conditions (as shown in Figure 10) decreased by $15 \%(10.7$ to $\left.9.1 \mathrm{~g} \mathrm{C} \mathrm{m}^{-2} \mathrm{~d}^{-1}\right)$ at DF49, $29 \%\left(7.5\right.$ to $\left.5.3 \mathrm{~g} \mathrm{C} \mathrm{m}^{-2} \mathrm{~d}^{-1}\right)$ at HDF88 and $26 \%$ (6.4 to $4.7 \mathrm{~g} \mathrm{C} \mathrm{m}^{-2} \mathrm{~d}^{-1}$ ) at HDF00 from values in moist conditions. This analysis suggests that the availability of soil water has a strong influence on $R_{e}$ and $P_{g}$ at the younger sites, especially at HDF88, consistent with the findings of Jassal et al. [2008a].

\section{Discussion}

\subsection{Effect of Stand Age}

[30] Our study indicates that the intersite differences in $F_{N E P}, P_{g}$ and $R_{\mathrm{e}}$ were much greater than the interannual variability. For the near-end-of rotation stand, there was greater control of the interannual variability in $F_{N E P}$ by $R_{e}$ whereas for the younger stands it was largely controlled by $P_{g}$ (Table 2). The relatively greater control by $P_{g}$ than $R_{e}$ has mainly been reported for boreal ecosystems [Barr et al., 2007; Krishnan et al., 2006; Zha et al., 2008] mainly because of the role of growing season length in those ecosystems in controlling the $\mathrm{C}$ balance. Based on long-term measurements of $\mathrm{C}$ exchange in a 75-110 year-old mixed-deciduous Harvard Forest in central Massachusetts, USA, Urbanski et al. [2007] reported that interannual variation in the annual $\mathrm{C}$ balance is mainly due to $P_{g}$. However, for a southern boreal black spruce forest, $R_{e}$ in years with a warm spring was found to control interannual variation [Krishnan et al., 2008]. Similar reports suggesting the dominant role of $R_{e}$ in controlling the annual $\mathrm{C}$ balance were made by Valentini et al. [2000], Bubier et al. [2003], and Dunn et al. [2007] for European forests, peatland in Ontario and a northern boreal black spruce forest, respectively.

[31] The intersite and interannual differences in $F_{N E P}$, $P_{g}$ and $R_{\mathrm{e}}$ for these three temperate Douglas-fir stands were higher than those reported for a boreal jack pine chronosequence (2-90 years) by Zha et al. [2008]. In our study, HDF88 became $\mathrm{C}$ neutral at about an age of 17 years whereas in the jack pine chronosequence, the ecosystems were reported to switch from a $\mathrm{C}$ source to sink of $\mathrm{C}$ at an age of about 10 years [Zha et al., 2008] and about 1119 years in a black spruce chronosequence [Bond-Lamberty et al., 2004]. Annual C loss $\left(F_{N E P}=-515 \pm 88 \mathrm{~g} \mathrm{C} \mathrm{m}^{-2} \mathrm{yr}^{-1}\right)$ following harvest at HDF00 (2-6 years) was higher than that reported for a 4-year-old Scots pine stand $\left(F_{N E P}=\right.$ $\left.-386 \mathrm{~g} \mathrm{C} \mathrm{m}^{-2} \mathrm{yr}^{-1}\right)$ [Kolari et al., 2004], a 2-year-old boreal jack pine stand $\left(F_{N E P}=-137 \mathrm{~g} \mathrm{C} \mathrm{m}^{-2} \mathrm{yr}^{-1}\right)[Z h a$ et al., 2008], a 3-year-old black spruce stand $\left(F_{N E P}=\right.$ $-124 \mathrm{~g} \mathrm{C} \mathrm{m}^{-2} \mathrm{yr}^{-1}$ ) [Bergeron et al., 2008].

[32] Harvesting influences the forest $\mathrm{C}$ balance components in different ways: because of the changes in aboveground and belowground biomass, it can induce soil warming and enrich soil organic matter that together with dead roots and logging debris can stimulate decomposition and enhance respiratory fluxes. Furthermore, harvesting can cause an increase in $\theta$ as a result of reduced $E$ following harvest, thus preventing the occurrence of dry-soil conditions that can limit soil respiration. Furthermore, $\mathrm{C}$ uptake by young stands is limited by the low LAI [Humphreys et al., 2005]. Grant et al. [2007] hypothesized that changes in $F_{N E P}$ during the aging of coastal Douglas-fir stands can be explained by changing nutrient uptake caused by different timescales for decomposition of fine nonwoody and coarse woody litter left after harvesting, a drop in canopy water potential with lengthening of the water uptake pathway during bole and branch growth, and increases in the ratio of autotrophic respiration to $P_{g}$ with phytomass accumulation.

\subsection{Effect of Temperature}

[33] In our study, the early growing season temperature had a significant positive effect on both annual $P_{g}$ and $R_{e}$ at all sites. Because of the greater response of $R_{e}$ than $P_{g}$ to temperature and an almost yearlong growing season, an increase in temperature during any part of the year could result in a decrease in $F_{N E P}$. A similar response of $P_{g}$ and $R_{e}$ to temperature and almost no dependence of $F_{N E P}$ on temperature was reported by Reichstein et al. [2007] based on an analysis of the determinants of the $\mathrm{C}$ balance using 93 site years of EC data from the EUROFLUX and CARBOEUROPE networks. Chen et al. [2002] reported that temperature had no significant influence on $\mathrm{CO}_{2}$ fluxes at the old-growth Douglas-fir-western hemlock forest stands in the Wind River Valley but it significantly affected $\mathrm{CO}_{2}$ exchange in the younger stands. The variations in $F_{N E P}$, $P_{g}$ and $R_{\mathrm{e}}$ in Figure 8 suggest that regardless of age, Douglas-fir stands responded similarly to the changes in $T_{\text {Spring }}$ and growing season $\theta$. A similar response was reported for the Douglas-fir stands at the Wind River site [Chen et al., 2002, 2004], which has a climate similar to that on the east coast of Vancouver Island, with the majority of $\mathrm{C}$ uptake occurring during early spring, followed by $\mathrm{C}$ loss in summer and little net $\mathrm{C}$ exchange in winter. In southern boreal aspen and black spruce forests an increase in spring temperature was found to increase annual $F_{N E P}, P_{g}$ and $R_{\mathrm{e}}$ [Black et al., 2000, 2005; Krishnan et al., 2006, 2008]. We found that the increase in summer or autumn temperature resulted in a decrease in $F_{N E P}$ and this effect was more noticeable at the younger sites than at DF49. This agrees with the findings of Piao et al. [2008] who analyzed EC $\mathrm{CO}_{2}$ flux measurements from 28 northern ecosystems. Since the magnitude of $\mathrm{C}$ loss at the younger sites during the latter part of the year was higher than the near-zero values at DF49, changes in temperature had more effect on annual $F_{N E P}$ at the younger sites than that at DF49.

\subsection{Effect of Changes in Water Availability}

[34] Our analysis suggests that dry soil conditions during the growing season had a significant effect on the C balance. While $R_{e}$ was controlled by temperature, soil moisture strongly influenced its response to temperature. Soil respiration $\left(R_{s}\right)$ measurements during 2003-2006 at DF49 suggested that more than $60 \%$ of $R_{e}$ is due to $R_{s}$ [Jassal et al., 2007]. Mean $R_{s}$ during May 2002 to December 2002 was found to be higher at HDF88 than that at DF49 and HDF00 [Humphreys et al., 2006]. The drying of the soil causes a large reduction in both hetero- 
trophic respiration and autotrophic respiration [Jassal et al., $2008 \mathrm{a}$ ]. Because of the large contribution of $R_{s}$, the decrease in $R_{e}$ could be largely due to the reduction in $R_{s}$. As shown in Figures 8, 9, and 10, HDF88 responded more to dry conditions than the other two sites. In a recent study using 2005-2006 soil chamber and EC measurement at HDF88, Jassal et al. [2008a] concluded that in extremely dry conditions, $R_{\mathrm{s}}$ is more influenced by $\theta$ than $T_{s}$. Figure 10 suggests that higher $\theta$ during the growing season has a strong effect on both $P_{g}$ and $R_{\mathrm{e}}$ at all sites. The slightly higher response of $R_{e}$ than $P_{g}$ resulted in a decrease in annual $F_{N E P}$ during the very wet year 2004 and an increase in annual $F_{N E P}$ during the dry years 1998 and 2006 at DF49. This is similar to the earlier report by Krishnan et al. [2008] for the SOBS forest in Saskatchewan. Direct evidence of an increase in $F_{N E P}$ with increasing rainfall during the growing season is reported mainly for grass ecosystems [Flanagan et al., 2002; Ma et al., 2007]. We found that the increase in $\theta$ during the growing season is more likely to decrease $F_{N E P}$ at DF49 due to the greater response of $R_{e}$ than $P_{g}$ to $\theta$, although it was found to be insignificant.

[35] Dry conditions reduce long-term photosynthetic rates as soil water becomes depleted in the root zone [Goulden et al., 1996; Reichstein et al., 2002; Griffis et al., 2004]. The reduction in $P_{g}$ could occur due to direct effects of soil water stress on carboxylation [Warren et al., 2003] or the decrease in stomatal conductance associated with soil water stress and high values of D [Farquhar and Sharkey, 1982; Baldocchi, 1997; Anthoni et al., 2002; Reichstein et al., 2002; Krishnan et al., 2006, 2008]. Because of the developed root system in mature stands, $P_{g}$ can be maintained due to the available water deep in the root zone whereas it appears that the impact of a shallower root zone on $P_{g}$ in the younger stands result in a greater reduction in $F_{N E P}$ (Figure 8 for 2004).

[36] Future climate projections forecast greater variability in precipitation and higher frequency of drought events in the mid and high latitudes [IPCC, 2007]. Earlier reports on drought effects focused on localized short-term and moderate drought [Law et al., 2001; Reichstein et al., 2002; Rambal et al., 2003; Ciais et al., 2005; Goulden et al., 1996; Baldocchi, 1997; Goldstein et al., 2000; Barford et al., 2001; Anthoni et al., 2002; Gu et al., 2006]. Recent reports are on regionalscale and long-term drought, e.g., the 2003 drought in Europe [Ciais et al., 2005; Granier et al., 2007; Reichstein et al., 2007] and the drought in Western North America in 2001-2003, which affected the southern boreal forest [Barr et al., 2007; Krishnan et al., 2006; Kljun et al., 2006]. All these studies suggested strong effects on the ecosystem $\mathrm{C}$ balance. Dry summers like those in 1998 and 2006, decreased $R_{e}$ more than $P_{g}$ resulting in an enhancement in $F_{N E P}$ in mature sites similar to that observed in the first year of drought in 2001 at the SOA forest [Barr et al., 2007; Krishnan et al., 2006; Kljun et al., 2006]. Drought early in the growing season or in spring or during canopy development can more strongly affect $P_{g}$ than $R_{e}$ resulting in a decreased annual $F_{N E P}$ as reported by Noormets et al. [2007] for a 50-year-old mixed-oak woodland in northern Ohio, USA and by Krishnan et al. [2006] for the third year of drought at the SOA forest. This effect will likely be greater for younger stands than mature stands as seen here at HDF88 and HDF00 in 2004.
[37] The impact of changes in water availability on $P_{g}$ and $R_{\mathrm{e}}$ likely depends on the water holding capacity of the soil, the vertical distribution of the amount of soil organic matter and roots in the soil and the general drought sensitivity of the vegetation [Heimann and Reichstein, 2008]. Warren et al. [2005], in a study of the vertical distribution of soil water in PNW old-growth ponderosa pine, young and old-growth Douglas fir stands, reported that the greater responsiveness of a young Douglas-fir stand to changes in $\theta$ was associated with the difference in the vertical distribution of root surface area in the young and old stands, which they attributed to developmental stage and stand density. They reported that total fine root biomass in the upper $1 \mathrm{~m}$ were higher for the young stand with $60 \%$ of the fine roots located in the upper $20 \mathrm{~cm}$. Studies conducted on young and old-growth ponderosa pine stands [Irvine et al., 2002; Anthoni et al., 2002] also showed higher drought stress in young stands than in old-growth forest because soil moisture was being extracted from greater depths at the old-growth site [Irvine et al., 2002]. In our study, high $E$ in younger stands with less developed root systems, similar in magnitude to that at DF49 during the growing season, could result in greater water uptake leading to water stress earlier in these stands than at DF49 for similar environmental conditions (Figure 2). Furthermore, the greater response of the younger stands (Figure 10), especially HDF88, to changes in $\theta$ could be due to the differences in soil physical and chemical characteristics at that site (Table 1). The greater response of HDF88 to $\theta$ is in contrast to the finding of McMillan et al. [2008] that younger stands were more susceptible to water or heat stress during a warm dry year. Even with the differences in stand density, LAI, basal area, soil characteristics, elevation, and proximity to the ocean, all sites showed similar responses when exposed to similar climate.

\subsection{Effect of ENSO and Climate Change on the Long-Term $C$ Balance}

[38] As mentioned above, ENSO plays an important role in year-to-year climate variability and hence potentially influences long-term trends in temperature and precipitation in the PNW [Mote et al., 1999; Mote, 2003]. The globally averaged growth rate of atmospheric $\mathrm{CO}_{2}$ is also tightly correlated to ENSO climate variations [Heimann and Reichstein, 2008] and with a warming planet the frequency of occurrence of stronger El Niño events is likely to increase. In a warmer climate, the change in precipitation distribution in the growing season is an important factor in controlling the $\mathrm{C}$ balance of ecosystems. The warmer conditions can extend the length of the effective growing season. As seen in our analysis, the extreme climatic conditions include a warm and mild winter followed by unusually warm spring months and a dry summer during El Niño (e.g., 1998), a wet winter and relatively cool and cloudy conditions in the following spring and summer during La Niña (e.g., 1999), and a warm winter and spring followed by a wet summer and autumn in neutral years (e.g., 2004 and 2005). As seen above, a warm spring and a wet growing season usually has a more positive effect on $P_{g}$ than $R_{e}$ at all the three sites. However, the increase in winter temperature can result in early enhancement of $R_{e}$ and reduce the number of days with positive $F_{N E P}$ in the early part of the growing season resulting in a reduction in annual $F_{N E P}$ at the near- 
end-of-rotation site. For the younger sites, this could increase the number of $\mathrm{C}$ uptake days in early part of the growing season and enhance annual $F_{N E P}$. The effect of dry versus wet conditions and their times of occurrence (early versus late in the growing season) are important in this ecosystem as shown in our analysis. While wet soil conditions early in the growing season can favor $P_{g}, R_{e}$ and $F_{N E P}$ (as in 2005), dry conditions in the latter part can reduce $R_{e}$ more than $P_{g}$ resulting in an enhancement of $F_{N E P}$ (as in 2006) at near-end-of-rotation site. However, wetter conditions in latter part of the growing season can enhance $R_{e}$ and decrease $F_{N E P}$ (e.g., 2004) at all three sites. The question of how each component $\left(P_{g}\right.$ or $\left.R_{e}\right)$ responds to changes in soil water availability and the impact on $F_{N E P}$ depends on the time of occurrence of dry and wet conditions. Almost parallel variations of $P_{g}$ and $R_{e}$ and the lack of a statistically significant relationship of $F_{N E P}$ to environmental variables suggest that we need to consider the impact of environmental variables on the $\mathrm{C}$ balance components rather than on $F_{N E P}$ when simulating the impact of a changing climate on the $\mathrm{C}$ balance. In addition, the increase in annual and autumn temperature had a negative effect on $F_{N E P}$, especially at the younger sites. The $\mathrm{C}$ balance of this ecosystem in the long-term will likely be determined by how the temperature-driven enhancement of $\mathrm{C}$ uptake in the early part of the growing season compares with the effect of changes in the soil water conditions or temperature during the latter part of the growing season.

\section{Conclusions}

[39] 1. Stand-age effects on $F_{N E P}, P_{g}$ and $R_{e}$ were much higher than that of interannual variability. The near-end of-rotation Douglas-fir stand, DF49, was a C sink (357 \pm $51 \mathrm{~g} \mathrm{C} \mathrm{m}^{-2} \mathrm{yr}^{-1}$ ) during 1998-2006 while the young plantation, HDF00, was a large $\mathrm{C}$ source $(-515 \pm$ $88 \mathrm{~g} \mathrm{C} \mathrm{m}^{-2} \mathrm{yr}^{-1}$ ) during 2002-2006. The pole-sapling stand, HDF88, was initially (2002-2004) a weak C source $\left(-105 \pm 10 \mathrm{~g} \mathrm{C} \mathrm{m}^{-2} \mathrm{yr}^{-1}\right)$ and in the last 2 years $(2005-$ 2006) was a weak sink $\left(21 \pm 30 \mathrm{~g} \mathrm{C} \mathrm{m}^{-2} \mathrm{yr}^{-1}\right)$.

[40] 2. Interannual variability in annual $F_{N E P}$ at DF49 was mainly due to interannual variability in annual $R_{e}$ whereas at the younger sites interannual variability in annual $P_{g}$ largely determined interannual variability in annual $F_{N E P}$.

[41] 3. Early growing season (spring) temperature and May-September (summer) soil water availability were the main factors determining the interannual variability in $P_{g}$ and $R_{e}$ of the three Douglas-fir stands. The linear relationship between annual $F_{N E P}$ and the above variables was not significant because of the similar changes in $P_{g}$ and $R_{\mathrm{e}}$. Even though not statistically significant, the decrease of $F_{N E P}$ with increasing spring, summer, autumn temperatures and growing season water content were due to a slightly greater response of $R_{e}$ than $P_{g}$ to the above climatic variables.

[42] 4. The impact of extremely dry conditions on $P_{g}$ and $R_{e}$ at the younger sites, especially at $\mathrm{HDF} 88$, was greater than at the near-end-of-rotation site, DF49. Drought conditions during the latter part of the growing season had a positive effect on $F_{N E P}$ because of the greater reduction in $R_{e}$ than $P_{g}$ in response to the decrease in $\theta$.
[43] 5. Empirical relationships using controlling environmental variables were effective in explaining more than $85 \%$ of the interannual variability in $P_{g}, R_{e}$ and $F_{N E P}$ at DF49; however, less than $40 \%$ could be explained using similar empirical relationships for the younger sites.

[44] Acknowledgments. This research was funded by the Natural Sciences and Engineering Research Council of Canada (NSERC), the Canadian Foundation for Climate and Atmospheric Science (CFCAS), and BIOCAP Canada Foundation through the Fluxnet Canada Research network (now the Canadian Carbon Program), and by a NSERC Discovery (operating) grant to T.A.B. We are grateful for assistance in laboratory and field from Andrew Sauter, Rick Ketler, Shawn O’Neill, Dominic Lessard, and Andrew Hum, and also for the data quality control by Elyn Humphreys, Christopher Schwalm, Nick Grant, Kai Morgenstern, Christian Bruemmer, and Adrian Leitch during the course of this research. Part of this research was performed while one of the authors (P.K.) held a National Research Council Associateship Award at NOAA/ATDD.

\section{References}

Amiro, B. D., et al. (2005), Carbon, energy and water fluxes at mature and disturbed forest sites, Saskatchewan, Canada, Agric. For. Meteorol., 136, 237-251, doi:10.1016/j.agrformet.2004.11.012.

Anthoni, P. M., M. H. Unsworth, B. E. Law, J. Irvine, D. D. Baldocchi, S. Van Tuyl, and D. Moore (2002), Seasonal differences in C and water vapor exchange in young and old-growth ponderosa pine ecosystems, Agric. For. Meteorol., 111, 203-222, doi:10.1016/S01681923(02)00021-7.

Baldocchi, D. (1997), Measuring and modelling carbon dioxide and water vapour exchange over a temperate broad-leaved forest during the 1995 summer drought, Plant Cell Environ., 20, 1108-1122, doi:10.1046/ j.1365-3040.1997.d01-147.x.

Barford, C. C., et al. (2001), Factors controlling long- and short-term sequestration of atmospheric $\mathrm{CO}_{2}$ in a mid-latitude forest, Science, 294, 1688-1691, doi:10.1126/science.1062962.

Barr, A. G., T. J. Griffis, T. A. Black, X. Lee, R. M. Staebler, J. D. Fuentes, Z. Chen, and K. Morgenstern (2002), Comparing the carbon balances of boreal and temperate deciduous forest stands, Can. J. For. Res., 32, 813-822, doi:10.1139/x01-131.

Barr, A. G., T. A. Black, E. H. Hogg, N. Kljun, K. Morgenstern, and $Z$. Nesic (2004), Inter-annual variability in the leaf area index of a boreal aspen-hazelnut forest in relation to net ecosystem production, Agric. For Meteorol., 126, 237-255, doi:10.1016/j.agrformet.2004.06.011.

Barr, A. G., T. A. Black, E. H. Hogg, T. J. Griffis, K. Morgenstern, N. Kljun, A. Theede, and Z. Nesic (2007), Climatic controls on the carbon and water balances of a boreal aspen forest, 1994-2003, Global Change Biol., 13, 561-576, doi:10.1111/j.1365-2486.2006.01220.x.

Bergeron, O., H. A. Margolis, C. Coursolle, and M. A. Giasson (2008), How does forest harvest influence carbon dioxide fluxes of black spruce ecosystems in eastern North America?, Agric. For. Meteorol., 148 , $537-548$.

Black, T. A., W. J. Chen, A. G. Barr, M. A. Arain, Z. Chen, Z. Nesic E. H. Hogg, H. H. Neumann, and P. C. Yang (2000), Increased carbon sequestration by a boreal deciduous forest in years with a warm spring, Geophys. Res. Lett., 27, 1271-1274, doi:10.1029/1999GL011234.

Black, T. A., D. Gaumont-Guay, R. S. Jassal, B. Amiro, P. J. Jarvis, T. Gower, F. Kelliher, A. Dunn, and S. Wofsy (2005), Measurement of $\mathrm{CO}_{2}$ exchange between boreal forest and the atmosphere, in The Carbon Balance of Terrestrial Biomes, edited by $\mathrm{H}$. Griffiths and P. J. Jarvis, pp. 120-141, Garland Sci., Oxford, U. K.

Bond-Lamberty, B., C. K. Wang, and S. T. Gower (2004), Net primary production and net ecosystem production of a boreal black spruce wildfire chronosequence, Global Change Biol., 10(4), 473-487, doi:10.1111/ j.1529-8817.2003.0742.x.

Bubier, J. L., G. Bhatia, T. R. Moore, N. T. Roulet, and P. M. Lafleur (2003), Spatial and temporal variability in growing season net ecosystem carbon dioxide exchange at a large peatland in Ontario, Canada, Ecosystems, 6, 353-367.

Campbell, G. S., and J. M. Norman (1998), An Introduction to Environmental Biophysics, Springer, New York.

Case, M. J., and D. L. Peterson (2005), Fine-scale variability in growthclimate relationships of Douglas-fir, North Cascade Range, Washington, Can. J. For. Res., 35, 2743-2755, doi:10.1139/x05-191.

Chen, B., T. A. Black, N. C. Coops, T. Hilker, J. A. Trofymow, and K. Morgenstern (2009), Assessing tower flux footprint climatology and scaling between remotely sensed and eddy covariance measurements, Boundary Layer Meteorol., 130, 137-167, doi:10.1007/s10546-0089339-1. 
Chen, J., M. Falk, E. Euskirchen, T. H. Suchanek, S. L. Ustin, B. J. Bond, K. D. Brosofske, N. Phillips, and R. Bi (2002), Biophysical controls of carbon flows in three successional Douglas-fir stands based on eddycovariance measurements, Tree Physiol., 22, 169-177.

Chen, J., T. P. U. Kyaw, S. L. Ustin, T. H. Suchanek, B. J. Bond, K. D. Brosofske, and M. Falk (2004), Net ecosystem exchanges of carbon, water, and energy in young and old-growth Douglas-fir forests, Ecosystems, 7, 534-544, doi:10.1007/s10021-004-0143-6.

Chen, J. M., A. Govind, O. Sonnentag, Y. Zhang, A. Barr, and B. Amiro (2006), Leaf area index measurements at Fluxnet Canada forest sites, Agric. For. Meteorol., 140, 257-268, doi:10.1016/j.agrformet.2006. 08.005 .

Ciais, P., M. Reichstein, N. Viovy, A. Granier, J. Ogee, V. Allard, M. Aubinet, N. Buchmann, C. Bernhofer, and A. Carrara (2005), Europewide reduction in primary productivity caused by the heat and drought in 2003, Nature, 437, 529-533, doi:10.1038/nature03972.

Clark, K. L., H. L. Gholz, and M. S. Castro (2004), Carbon dynamics along a chronosequence of slash pine plantations in north Florida, Ecol. Appl., 14, 1154-1171, doi:10.1890/02-5391.

Cramer, W., et al. (2001), Global response of terrestrial ecosystem structure and function to $\mathrm{CO}_{2}$ and climate change: Results from six dynamic global vegetation models, Global Change Biol., 7, 357-373, doi:10.1046 j.1365-2486.2001.00383.x.

Drewitt, G., T. Black, Z. Nesic, E. Humphreys, E. Jork, R. Swanson, G. Ethier, T. Griffis, and K. Morgenstern (2002), Measuring forest floor $\mathrm{CO}_{2}$ fluxes in a Douglas-fir forest, Agric. For. Meteorol., 110, 299-317, doi:10.1016/S0168-1923(01)00294-5.

Dunn, A. L., C. C. Barford, S. C. Wofsy, M. L. Goulden, and B. C. Daube (2007), A long-term record of carbon exchange in a boreal black spruce forest: Means, responses to interannual variability, and decadal trends, Global Change Biol., 13, 577-590, doi:10.1111/j.1365-2486.2006. 01221.x.

Farquhar, G. D., and T. D. Sharkey (1982), Stomatal conductance and photosynthesis, Annu. Rev. Plant Physiol., 33, 317-345, doi:10.1146/ annurev.pp.33.060182.001533.

Flanagan, L. B., L. A. Wever, and P. J. Carlson (2002), Seasonal and interannual variation in carbon dioxide exchange and carbon balance in a northern temperate grassland, Global Change Biol., 8, 599-615, doi:10.1046/j.1365-2486.2002.00491.x.

Goldstein, A. H., N. E. Hultman, J. M. Fracheboud, M. R. Bauer, J. A. Panek, M. Xu, Y. Qi, A. B. Guenther, and W. Baugh (2000), Effects of climate variability on the carbon dioxide, water, and sensible heat fluxes above a ponderosa pine plantation in the Sierra Nevada (CA), Agric. For Meteorol., 101, 113-129, doi:10.1016/S0168-1923(99)00168-9.

Goulden, M. L., W. Munger, S. M. Fan, and B. C. Daube (1996), Measurements of carbon sequestration by long-term eddy covariance: Methods and a critical evaluation of accuracy, Global Change Biol., 2, 169-182, doi:10.1111/j.1365-2486.1996.tb00070.x.

Granier, A., et al. (2007), Evidence for soil water control on carbon and water dynamics in European forests during the extremely dry year: 2003 , Agric. For. Meteorol., 143, 123-145, doi:10.1016/j.agrformet.2006. 12.004

Grant, R., T. Black, E. Humphreys, and K. Morgenstern (2007), Changes in net ecosystem productivity with forest age following clear-cutting of a coastal Douglas-fir forest: Testing a mathematical model with eddy covariance measurements along a forest chronosequence, Tree Physiol., $27,115-131$

Griffis, T., T. Black, K. Morgenstern, A. Barr, Z. Nesic, G. Drewitt, D. Gaumont-Guay, and J. McCaughey (2003), Ecophysiological controls on the carbon balances of three southern boreal forests, Agric. For. Meteorol., 117, 53-71, doi:10.1016/S0168-1923(03)00023-6.

Griffis, T. J., T. A. Black, D. Gaumont-Guay, G. B. Drewitt, Z. Nesic, A. G. Barr, K. Morgenstern, and N. Kljun (2004), Seasonal variation and partitioning of ecosystem respiration in a southern boreal aspen forest, Agric. For. Meteorol., 125, 207-223, doi:10.1016/j.agrformet. 2004.04.006.

Gu, L., T. Meyers, S. G. Pallardy, P. J. Hanson, B. Yang, M. Heuer, K. P. Hosman, J. S. Riggs, D. Sluss, and S. D. Wullschleger (2006) Direct and indirect effects of atmospheric conditions and soil moisture on surface energy partitioning revealed by a prolonged drought at a temperate forest site, J. Geophys. Res., 111, D16102, doi:10.1029/ 2006JD007161

Heimann, M., and M. Reichstein (2008), Terrestrial ecosystem carbon dynamics and climate feedbacks, Nature, 451, 289-292, doi:10.1038/ nature 06591

Hermann, R. K. (1985), The genus Pseudotsuga: Ancestral history and past distribution, Spec. Publ. $2 b$, For. Res. Lab., Sch. of For., Oreg. State Univ., Corvallis

Humphreys, E., T. Black, G. Ethier, G. Drewitt, D. Spittlehouse, E. Jork, Z. Nesic, and N. Livingston (2003), Annual and seasonal variability of sensible and latent heat fluxes above a coastal Douglas-fir forest, British Columbia, Canada, Agric. For. Meteorol., 115, 109-125, doi:10.1016 S0168-1923(02)00171-5.

Humphreys, E., T. Andrew Black, K. Morgenstern, Z. Li, and Z. Nesic (2005), Net ecosystem production of a Douglas-fir stand for 3 years following clear-cut harvesting, Global Change Biol., 11, 450-464, doi:10.1111/j.1365-2486.2005.00914.x.

Humphreys, E., T. Black, K. Morgenstern, T. Cai, G. Drewitt, Z. Nesic, and J. Trofymow (2006), Carbon dioxide fluxes in coastal Douglas-fir stands at different stages of development after clear-cut harvesting, Agric. For. Meteorol., 140, 6-22, doi:10.1016/j.agrformet.2006.03.018. Intergovernmental Panel on Climate Change (IPCC) (2007), Climate Change 2007: Impacts, Adaptation and Vulnerability. Contribution of Working Group II to the Fourth Assessment Report of the Intergovernmental Panel on Climate Change, edited by M. L. Parry et al., Cambridge Univ. Press, Cambridge, U. K.

Irvine, J., B. E. Law, P. M. Anthoni, and F. C. Meinzer (2002), Water limitations to carbon exchange in old-growth and young ponderosa pine stands, Tree Physiol., 22, 189-196.

Jassal, R. S., T. A. Black, T. B. Cai, K. Morgenstern, Z. Li, D. GaumontGuay, and Z. Nesic (2007), Components of ecosystem respiration and an estimate of net primary productivity of an intermediate-aged Douglas-fir stand, Agric. For. Meteorol., 144, 44-57, doi:10.1016/j.agrformet. 2007.01.011.

Jassal, R. S., T. A. Black, B. Chen, R. Roy, Z. Nesic, D. L. Spittlehouse, and J. A. Trofymow (2008a), $\mathrm{N}_{2} \mathrm{O}$ emissions and carbon sequestration in a nitrogen-fertilized Douglas fir stand, J. Geophys. Res., 113, G04013, doi:10.1029/2008JG000764

Jassal, R. S., T. A. Black, M. D. Novak, D. Gaumont-Guay, and Z. Nesic (2008b), Effect of soil water stress on soil respiration and its temperature sensitivity in an 18-year-old temperate Douglas-fir stand, Global Change Biol., 14, 1-14, doi:10.1111/j.1365-2486.2008.01573.x.

Keeling, C. D., J. F. S. Chin, and T. P. Whorf (1996), Increased activity of northern vegetation inferred from atmospheric $\mathrm{CO}_{2}$ measurements, Nature, 382, 146-149, doi:10.1038/382146a0.

Kelliher, F. M., R. Leuning, and E. D. Schulze (1993), Evaporation and canopy characteristics of coniferous forest and grasslands, Oecologia, 95 , 153-163, doi:10.1007/BF00323485.

Kljun, N., T. A. Black, T. J. Griffis, A. G. Barr, D. Gaumont-Guay, K. Morgenstern, J. H. McCaughey, and Z. Nesic (2006), Response of net ecosystem productivity of three boreal forest stands to drought, Ecosystems, 9, 1128-1144, doi:10.1007/s10021-005-0082-x.

Kolari, P., J. Pumpanen, Ü. Rannik, H. Ilvesniemi, P. Hari, and F. Berninger (2004), Carbon balance of different aged Scots pine forests in southern Finland, Global Change Biol., 10, 1106-1119, doi:10.1111/j.1529-8817. 2003.00797.x.

Krishnan, P., T. Black, N. Grant, A. Barr, E. Hogg, R. Jassal, and K. Morgenstern (2006), Impact of changing soil moisture distribution on net ecosystem productivity of a boreal aspen forest during and following drought, Agric. For. Meteorol., 139, 208-223, doi:10.1016/j.agrformet. 2006.07.002.

Krishnan, P., T. A. Black, A. G. Barr, N. J. Grant, D. Gaumont-Guay, and Z. Nesic (2008), Factors controlling the interannual variability in the carbon balance of a southern boreal black spruce forest, J. Geophys. Res., 113, D09109, doi:10.1029/2007JD008965.

Law, B., F. Kelliher, D. Baldocchi, P. Anthoni, J. Irvine, D. Moore, and and and S. Van Tuyl (2001), Spatial and temporal variation in respiration in a young ponderosa pine forests during a summer drought, Agric. For Meteorol., 110, 27-43, doi:10.1016/S0168-1923(01)00279-9.

Lindroth, A., A. Grelle, and A. S. Moren (1998), Long-term measurements of boreal forest carbon balance reveal large temperature sensitivity, Global Change Biol., 4, 443-450, doi:10.1046/j.1365-2486.1998.00165.x.

Ma, S., D. D. Baldocchi, L. Xu, and T. Hehn (2007), Inter-annual variability in carbon dioxide exchange of an oak/grass savanna and open grassland in California, Agric. For. Meteorol., 147, 157-171, doi:10.1016/j.agrformet. 2007.07.008.

McMillan, A. M. S., G. C. Winston, and M. L. Goulden (2008), Agedependent response of boreal forest to temperature and rainfall variability, Global Change Biol., 14, 1904-1916, doi:10.1111/j.1365-2486.2008. 01614.x

Meidinger, D. V., and J. Pojar (1991), Ecosystems of British Columbia, Res. Branch, Minist.of For., Victoria, B. C., Canada.

Monteith, J. L., and M. H. Unsworth (1990), Principles of Environmental Physics, 291 pp., Edward Arnold, London.

Morgenstern, K., T. A. Black, E. R. Humphreys, T. J. Griffis, G. B. Drewitt, T. Cai, Z. Nesic, D. L. Spittlehouse, and N. J. Livingston (2004), Annual variations in carbon sequestration during an El Niño/La Niña cycle in a coastal Douglas-fir forest, Agric. For. Meteorol., 123, 201-219, doi:10.1016/j.agrformet.2003.12.003. 
Mote, P. W. (2003), Trends in snow water equivalent in the Pacific Northwest and their climatic causes, Geophys. Res. Lett., 30(12), 1601, doi:10.1029/2003GL017258.

Mote, P., D. Canning, D. Fluharty, R. Francis, J. Franklin, A. Hamlet, M. Hershman, M. Holmberg, K. G. Ideker, and W. Keeton (1999), Impacts of climate variability and change: Pacific Northwest, 110 pp., JISAO Clim. Impacts Group, Univ. of Wash., Seattle.

Myneni, R. B., C. D. Keeling, C. J. Tucker, G. Asrar, and R. R. Neman (1997), Increased plant growth in the northern high latitudes from $1981-$ 1991, Nature, 386, 698-702, doi:10.1038/386698a0.

Noormets, A., et al. (2007), Moisture sensitivity of ecosystem respiration: Comparison of 14 forest ecosystems in the Upper Great Lakes Region, USA, Agric. For. Meteorol, doi:10.1016/j.agrformet.2007.08.002.

Piao, S., et al. (2008), Net carbon dioxide losses of northern ecosystems in response to autumn warming, Nature, 451, 49-53, doi:10.1038/ nature 06444.

Ponton, S., L. Flanagan, K. Alstad, B. Johnson, K. Morgenstern, N. Kljun T. Black, and A. Barr (2006), Comparison of ecosystem water use efficiency among Douglas-fir forest, aspen forest and grassland using eddy covariance and carbon isotope techniques, Global Change Biol., 12, 294-310, doi:10.1111/j.1365-2486.2005.01103.x.

Rambal, S., J. M. Ourcival, R. Joffre, F. Mouillot, Y. Nouvellon, M. Reichstein, and A. Rocheteau (2003), Drought controls over conductance and assimilation of a Mediterranean evergreen ecosystem: Scaling from leaf to canopy, Global Change Biol., 9, 1813-1824, doi:10.1111/j.1365-2486. 2003.00687.x.

Rasmussen, E. M., and J. M. Wallace (1983), Meteorological aspects of the El Nino Southern Oscillation, Science, 222, 1195-1202, doi:10.1126/ science.222.4629.1195.

Reichstein, M., J. D. Tenhunen, O. Roupsard, J. M. Ourcival, S. Rambal F. Miglietta, A. Peressotti, M. Pecchiari, G. Tirone, and R. Valentini (2002), Severe drought effects on ecosystem $\mathrm{CO}_{2}$ and $\mathrm{H}_{2} \mathrm{O}$ fluxes at three Mediterranean evergreen sites: Revision of current hypotheses?, Global Change Biol., 8, 999-1017, doi:10.1046/j.1365-2486.2002.00530.x.

Reichstein, M., et al. (2007), Determinants of terrestrial ecosystem carbon balance inferred from European eddy covariance flux sites, Geophys. Res. Lett., 34, L01402, doi:10.1029/2006GL027880.

Schimel, D. S., et al. (2001), Recent patterns and mechanisms of carbon exchange by terrestrial ecosystems, Nature, 414, 169-172, doi:10.1038/ 35102500 .

Schulze, E.-D., et al. (1999), Productivity of forests in the Eurosiberian boreal region and their potential to act as a carbon sink-A synthesis, Global Change Biol., 5, 703-722, doi:10.1046/j.1365-2486.1999. 00266.x.

Schwalm, C. R., T. A. Black, K. Morgenstern, and E. R. Humphreys (2007), A method for deriving net primary productivity and component respiratory fluxes from tower-based eddy covariance data: A case study using a 17-year data record from a Douglas-fir chronosequence, Global Change Biol., 13, 370-385, doi:10.1111/j.1365-2486.2006.01298.x.

Sellers, P. J., et al. (1997), BOREAS in 1997: Experiment overview, scientific results, and future directions, J. Geophys. Res., 102, 28,731-28,770, doi:10.1029/97JD03300.
Shabbar, A., and M. L. Khandekar (1996), The impact of El Nino/Southern Oscillation on the temperature field over Canada, Atmos. Ocean, 34, $401-416$

Shabbar, A., B. Bonsal, and M. Khandekar (1997), Canadian precipitation patterns associated with the Southern Oscillation, J. Clim., 10, 3016-3027, doi:10.1175/1520-0442(1997)010<3016:CPPAWT> 2.0.CO;2.

Smithwick, E. A. H., M. E. Harmon, S. M. Remillard, S. A. Acker, and J. F. Franklin (2002), Potential upper bounds of carbon stores in forests of the Pacific Northwest, Ecol. Appl., 12, 1303-1317, doi:10.1890/ 1051-0761(2002)012[1303:PUBOCS]2.0.CO;2

Turner, D. P., G. J. Koerper, M. E. Harmon, and J. J. Lee (1995), A carbon budget for forests of the conterminous United States, Ecol. Appl., 5, 421-436, doi: $10.2307 / 1942033$.

Turner, D. P., W. B. Cohen, and R. E. Kennedy (2000), Alternative spatial resolutions and estimation of carbon flux over a managed forest landscape in Western Oregon, Landscape Ecol., 15, 441-452, doi:10.1023/ A:1008116300063.

Urbanski, S., et al. (2007), Factors controlling $\mathrm{CO}_{2}$ exchange on timescales from hourly to decadal at Harvard Forest, J. Geophys. Res., 112, G02020, doi:10.1029/2006JG000293.

Valentini, R., et al. (2000), Respiration as the main determinant of carbon balance in European forests, Nature, 404, 861-865, doi:10.1038/ 35009084

Waring, R. H., and J. F. Franklin (1979), Evergreen coniferous forests of the Pacific Northwest, Science, 204, 1380-1386, doi:10.1126/ science.204.4400.1380.

Warren, C. R., G. J. Ethier, N. J. Livingston, N. J. Grant, D. H. Turpin, D. L. Harrison, and T. A. Black (2003), Transfer conductance in second growth Douglas-fir (Pseudotsuga menziesii (Mirb.) Franco) canopies, Plant Cell Environ., 26, 1215-1227, doi:10.1046/j.1365-3040. 2003.01044.x.

Warren, J. M., F. C. Meinzer, J. R. Brooks, and J. C. Domec (2005), Vertical stratification of soil water storage and release dynamics in Pacific Northwest coniferous forests, Agric. For. Meteorol., 130, 39-58, doi:10.1016 j.agrformet.2005.01.004.

Xu, L. K., and T. C. Hsiao (2004), Predicted versus measured photosynthetic water use efficiency of crop stands under dynamically changing field environments, J. Exp. Bot., 55, 2395-2411, doi:10.1093/jxb/erh271. Zha, T., et al. (2008), Carbon sequestration in boreal jack pine stands following harvesting, Global Change Biol., 15, 1475-1487, doi:10.1111/ j.1365-2486.2008.01817.x.

T. A. Black, R. S. Jassal, and Z. Nesic, Biometeorology and Soil Physics Group, Faculty of Land and Food Systems, University of British Columbia, Vancouver, BC V6T 1Z4, Canada.

B. Chen, Institute of Geographic Science and Natural Resources Research, Chinese Academy of Sciences, Number 11A, Datun Road, Anwai, Beijing 100101, China

P. Krishnan, Atmospheric Turbulence and Diffusion Division, NOAA, Oak Ridge, TN 37830, USA. (praveena.krishnan@noaa.gov) 